\title{
Scleritis and episcleritis
}

\author{
PETER G. WATSON* AND SOHAN SINGH HAYREH $†$ \\ From Moorfields Eye Hospital, City Road, London*, and Addenbrooke's Hospital, Cambridge*, \\ and the Department of Ophthalmology, University of Iowa Hospitals and Clinics, Iowa City, USA†
}

From the earliest available descriptions of episcleritis (Slade, 1838; Rognetta, 1844; Desmarres, 1847) a confusion has existed between scleritis and episcleritis. This has led to contradictory views on the relative severity and prognosis of these conditions, and the erroneous belief that episcleritis is accompanied by serious complications (Viswalingham, 1936; Wood, 1936; Mann and Markson, 1950; Clavel and Teulières, 1958). While Slade (1838), Rognetta (1844), and Desmarres (1847), thought that episcleritis was both common and severe, Mackenzie (1830) considered it to be neither and gave at the same time a vivid and accurate description of scleritis. This confusion still persists today.

In an attempt to clarify the position we have been studying patients with scleritis and episcleritis in a special clinic at Moorfields Eye Hospital during the past 10 years. Of these, 207 patients (301 eyes) with episcleritis and 159 patients (217 eyes) with scleritis were analysed in depth. $\S$ The results reported below have led us to conclude that scleritis and episcleritis are clinically distinct, with a different symptomatology and prognosis and requiring different management.

The incidence of these conditions is not known, but Williamson (1974) suggested that it was about 0.08 per cent of hospital new patient referrals. Our series is from highly selected patients, all being referred from elsewhere, often where there was difficulty in diagnosis, and with unusual problems. This is reflected in the fact that 90 per cent of the patients who had rheumatoid arthritis were seen within a year of the start of the special clinic.

\section{Classification}

EPISCLERITIS

Episcleritis has been recognized for over a century, although called by many different names, such as subconjunctivitis by von Graefe (Duke-Elder and

\$Mr B. Augier and Mrs B. Phillips of the Institute of Ophthalmology; London, used the University of London computer to analyse the findings

Address for reprints: 22 Parkside, Cambridge, England*, or University of Iowa, Iowa City, Iowa 52242, USA $†$
Leigh, 1965), subconjunctival phlegma or simple or phlegmatous conjunctivitis by Mackenzie (1830), and episcleritis periodica fugax by Fuchs (1895). Duke-Elder and Leigh (1965) distinguished between nodular episcleritis and rheumatic episcleritis, but such a differentiation appears to be unjustified as rheumatoid arthritis can be associated with either condition. We have classified episcleritis into two types:

I. Simple episcleritis

2. Nodular episcleritis.

\section{SCLERITIS}

Many classifications of scleral disease have been proposed (Holthouse, 1893; van der Hoeve, 1934; Franceschetti and Bischler, 1950; DukeElder and Leigh, 1965; Sevel, 1967) which have been based on a mixture of clinical and pathological observations. Although we tried to adopt these, from the clinical point of view they have all been unsatisfactory. We eventually adopted the following classification because, although there is some slight overlap between the groups, clinically we have observed several distinct patterns. This classification has proved to be satisfactory and has enabled us to assign almost all the patients to a particular category at the initial examination.

(a) Anterior scleritis

I. Diffuse scleritis

2. Nodular scleritis

3. Necrotizing scleritis

$a$. with inflammation

b. without inflammation (scleromalacia perforans)

(b) Posterior scleritis.

\section{Material}

Using the above classification, patients were distributed as in Table I.

\section{Normal anatomy}

Before considering the criteria by which the differential diagnosis is reached it is necessary to 
understand the normal vascular anatomy of the outer coats of the eye. The blood vessels of the episclera are not easily seen in the uninflamed eye, but as soon as the eye becomes congested three quite separate vascular plexuses become readily visible.

\section{Bulbar conjunctival plexus (Fig. I)}

This is the most superficial plexus of fine hair-like interlacing vessels freely moveable over the underlying structures. Overlying the episclera the conjunctival arteries are derived from two sourcesthe anterior ciliary arteries at the limbus, and the palpebral branches of the ophthalmic and lacrimal arteries. When they are inflamed the colour is bright red.

\section{Episcleral plexus (Fig. I)}

The vessels, which are straight and radially arranged, lie in the superficial episclera (parietal layer of Tenon's capsule) at a depth of about onequarter to one-third of the distance between the surface of the conjunctiva and sclera (Graves, 1937). The visible vessels are mainly veins, accepting the aqueous veins at intervals around the globe. These vessels are moveable over the deep layers, although not so easily as the conjunctival vessels. In the anterior episcleral plexus (anterior to the equator and over the muscle) the vessels belong to the anterior ciliary system; while in the posterior episcleral arterial plexus (posterior to the equator) they are derived from the arteries of the oblique muscles, the posterior ciliary arteries, and the vessels of the optic nerve sheaths (Hayreh and Baines, 1972). When inflamed, these radially arranged vessels can easily be seen, giving the eye a salmon pink colour.

\section{Scleral (deep episcleral) plexus (Fig. I)}

This plexus consists of a rete (criss-cross) of vessels lying within the visceral layer of Tenon's capsule, closely applied to the sclera. At the limbus the superficial and deep episcleral plexuses merge into one another and terminate in the superficial marginal plexuses of the cornea. When congested this layer looks bluish-red in colour and is immobile.

\section{Clinical examination}

Careful examination will determine the depth of the inflammation, so that it is almost always possible to decide when the patient is first seen whether scleritis or episcleritis is present. This depends on accurate observation of the relationship of one layer of vessels to the other and to the underlying sclera.

\section{HISTORY}

A detailed clinical history is taken of the patient's ocular and systemic disorders, including family history. Any contact with chemical irritants and solvents is noted, as is any history of allergic conditions, rheumatic, connective-tissue or skin disease, gout, venereal disease, tuberculosis, or sarcoidosis. The site, distribution, and nature of any ocular pain and disturbances of vision are important in deciding the type of inflammation present.

\section{EXAMINATION OF THE EYE}

After the visual acuity has been recorded, the following routine of examination is used:

\section{External examination of the eye in daylight}

It is essential to examine a case of episcleritis in daylight as this is often the only way of distin-

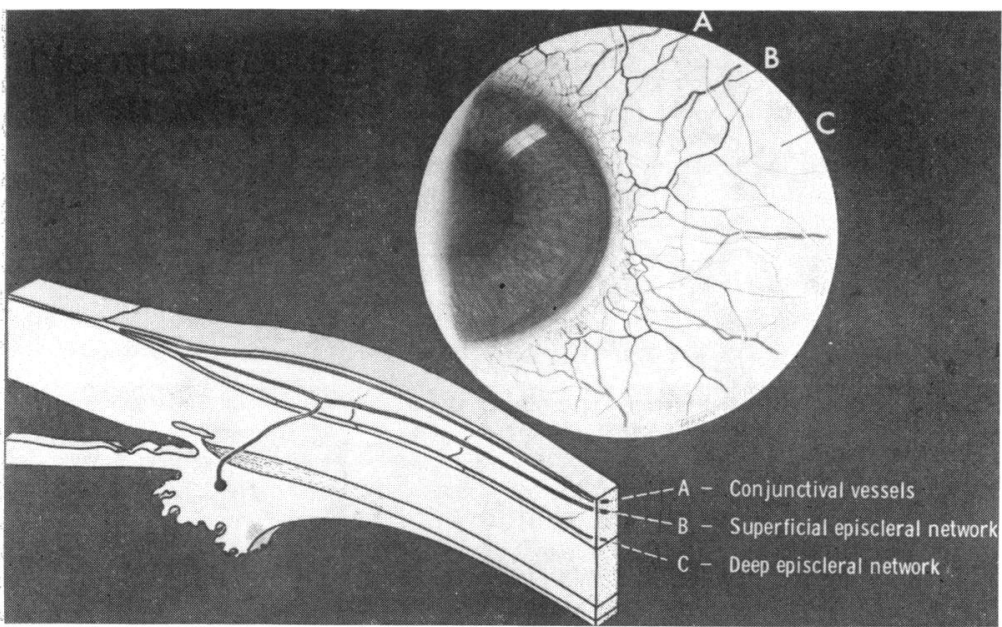

FIG. I Normal vascular networks of episclera. There are three layersthe deepest is almost invisible in the uninflamed eye 
guishing episcleritis from the much more serious scleral disease. In episcleritis the colour is salmon pink; in deep scleral disease the colour has a much deeper purple hue. These colour changes are difficult to distinguish in tungsten or fluorescent light. After recurrent attacks of scleral inflammation the sclera may become more transparent and is sometimes thinner, and as a consequence the grey choroid may be seen through the sclera. Sometimes these areas are black and well defined, but more often they give a faint grey tinge to the sclera. This is a particularly important observation in scleromalacia perforans, in which there is no surrounding inflammation. Time and again it is possible to see areas of scleral thinning in daylight which were invisible with the slit-lamp or by illumination with tungsten or fluorescent light.

\section{Slit-lamp microscopic examination}

Of the greatest assistance in distinguishing episcleritis from scleritis is the relationship of one vascular network with another and the changes within them. The object of this examination is to confirm the macroscopic findings. In scleritis, the examination is directed to detecting scleral oedema and the involvement of scleral vessels, ignoring the fact that the overlying episclera will be congested and oedematous. In episcleritis there will be no oedema of the sclera. In addition avascular patches must be diligently searched for, as these indicate a vasculitis and carry a poor prognosis.

Diffuse illumination confirms the macroscopic impression that only episcleral tissue is involved, and in addition reveals any corneal changes.

Slit-lamp examination detects the depth of maximum vascular involvement, infiltration, and oedema of the episclera. Any corneal changes can be categorized and the anterior segment and vitreous scrutinized for evidence of uveitis.

Red-free light examination should never be omitted; it is the ideal method of examining the vascular changes because the vessels become more easily visible. Infiltration of the episclera also shows up as a yellow patch. Adrenaline $\mathrm{r}: 1000$ or ro per cent phenylephrine can be instilled into the conjunctival sac. This constricts the conjunctival and superficial episcleral vessels more than the deep scleral plexus, thus revealing any underlying scleral disease.

\section{General eye examination}

It is essential to exclude complications such as glaucoma, uveitis, pars planitis, choroiditis, secon- dary retinal detachment, and optic neuritis. Proptosis and limitation of movement of the extraocular muscles are also looked for as evidence of an involvement of posterior sclera.

\section{SYSTEMIC EXAMINATION}

As scleritis is frequently a manifestation, and sometimes the first manifestation, of systemic disease, a thorough physical examination is imperative, special attention being paid to the joints and the cardiovascular system to eliminate a vasculitis.*

\section{Special investigations}

ROUTINE STUDIES CARRIED OUT IN ALL PATIENTS

\section{Full blood count}

This included haemoglobin estimation, white blood cell count and differential white cell count, and erythrocyte sedimentation rate.

\section{Rheumatoid arthritis latex agglutination test}

The Rose-Waaler sheep-cell agglutination test was used as a confirmatory test for rheumatoid factor.

\section{Serum uric acid estimation}

\section{Serological tests for syphilis}

A patient who had a positive Wassermann reaction also had the fluorescent treponemal antibody absorption (FTA (ABS)) test, Reiter's complement-fixation test, the Venereal Disease Reference Laboratory (VDRL) test, and the Treponema pallidum immobilization (TPI) test to confirm the diagnosis of syphilis. It was recognized that some cases of syphilis might have been missed as only the Wassermann and Kahn tests were performed as a routine. In the case of any abnormal result the test was repeated.

\section{X-rays of the chest and sacro-iliac joints}

These were taken whether the patient had any relevant complaints or not.

\section{ADDITIONAL STUDIES CARRIED OUT IN CERTAIN PATIENTS}

I. A full immunological survey for tissue antibodies, soluble immune complexes, complement, lupus erythematosus cells, and antinuclear factor (ANF) were undertaken.

2. Mantoux test.

3. Electroretinograms and electro-oculograms were

* This was carried out in our clinic by the rheumatologists Dr Fowler, Dr Hazleman, and Dr Lachmann 
performed initially in all patients but later in the series these were confined to patients with severe disease and to all those with posterior scleritis.

\section{Results}

\section{PATIENTS}

The data were derived from 207 patients (301 eyes) with scleritis and 159 patients (217 eyes) with episcleritis (Table I).

\section{FAMILY HISTORY}

A family history was elicited in 14 patients (four of these patients had simple episcleritis, three nodular episcleritis, six nodular scleritis, and one diffuse anterior scleritis). In the case of the three patients with nodular scleritis the condition was very similar to that seen in close relatives, but in all others the history was indefinite. This indicates that neither episcleritis nor scleritis is a familial condition.

\section{TIME BETWEEN ONSET AND FIRST ATTENDANCE}

In contrast to episcleritis, patients with scleritis attended much sooner after the onset of the disease, but even so (presumably because the onset was often insidious) many patients did not seek advice until the pain had become severe, which might not have been for several weeks. Of the patients with episcleritis 13 per cent reported in the first month and 64 per cent within two months. Of those with scleritis the results were very similar, 37 per cent being seen within the first month and 68 per cent before the end of the second month.

Table I Patients with episcleritis and scleritis whose records were analysed by computer

\begin{tabular}{|c|c|c|c|c|}
\hline Diagnosis & Patients & Eyes & $\begin{array}{l}\text { Further } \\
\text { subdivisions }\end{array}$ & Eyes \\
\hline Episcleritis & 159 & 217 & $\begin{array}{l}\text { Simple } \\
\text { Nodular }\end{array}$ & $\begin{array}{r}170 \\
47\end{array}$ \\
\hline Scleritis & 207 & 301 & $\begin{array}{l}\text { Diffuse anterior } \\
\text { Nodular anterior } \\
\text { *Necrotizing } \\
\text { with } \\
\text { inflammation } \\
\text { without } \\
\text { inflammation } \\
\text { Posterior }\end{array}$ & $\left.\begin{array}{r}119 \\
134 \\
29 \\
13 \\
6\end{array}\right\}$ \\
\hline
\end{tabular}

*The incidence of necrotizing anterior scleritis is open to question because, although sometimes obvious when the patient first presents, the disease more often starts as a diffuse or nodular anterior scleritis. Active treatment has certainly prevented some patients from developing necrotic lesions. Only those patients whose diagnosis was absolutely certain have been included in this category
Within one year of the onset of this condition 92 per cent had sought advice.

\section{AGE AND SEX DISTRIBUTION}

Scleritis was more than $I \frac{1}{2}$ times as common in women as in men. This contrasted with episcleritis, which was equally common in both sexes.

\section{Scleritis}

Analysis of the age and sex distribution for the different types of scleritis revealed distinct patterns for each type of scleritis. The diffuse and nodular varieties were most prevalent. In men the peak incidence occurred in the fourth decade $(\mathrm{P}=<0.05)$; women showed two separate peak incidences, one in the third decade and another in the sixth decade $(P=<0.05)$.

\section{Scleritis-diffuse anterior scleritis}

In women the disease was commonest in the fourth to seventh decades, with no predilection for any age group. In men it was more prevalent in the third to sixth decades, with a distinct peak during the fourth. The condition was rare in the young and the old.

\section{Scleritis-nodular anterior scleritis}

The nodular disease in both sexes was most prevalent from the fourth to sixth decades, but in women there was a very marked peak during the sixth decade.

\section{Scleritis-necrotizing type with inflammation}

Of the patients who presented with this severe variety of scleritis the majority were women, but of those who presented during the fourth decade all but one were men.

\section{Scleritis-necrotizing type without inflammation (scleromalacia perforans)}

All these patients were women. The age range was 35 to 75 years, most cases occurring in the fifth decade.

\section{Scleritis-posterior scleritis}

Posterior scleritis was usually associated with a diffuse anterior scleritis, occurring most frequently in women in their sixth decade, but one woman of 35 years was seen with this condition.

\section{Episcleritis}

Altogether 88 men and $7 \mathrm{I}$ women suffered from episcleritis. There was a significant variation in the 
sex distribution at different ages. The condition was not seen in childhood. Episcleritis in men occurred maximally from the third to the sixth decade, with a peak in the fourth decade. In women, however, although there was a peak incidence in the fourth and fifth decades, the distribution did not show a predilection for any particular age group. The difference between the peak incidence in the different series was highly significant $(P=<0.005)$. There was no significant difference in the sexes between the time of onset of simple and nodular episcleritis, but nodular episcleritis had a peak incidence in the fifth decade whereas simple episcleritis was most common in the fourth decade $(P=<0.05)$.

\section{INVOLVEMENT OF ONE OR BOTH EYES}

\section{Scleritis}

In 45 per cent of the patients the disease was bilateral, but in cases in which the disease involved only one eye, one side was not involved more than the other. When each type of scleritis was further analysed it showed that diffuse anterior scleritis was more often bilateral $(\mathrm{P}=<0.005)$ and that nodular anterior scleritis was more often unilateral $(P=<0.005)$. In necrotizing scleritis with inflammation both eyes were more often affected than in patients with scleromalacia perforans. These differences were not, however, significant.

Posterior scleritis was usually unilateral.

In 35 per cent of those patients in whom the condition became bilateral, the other eye was affected between one and three months after the onset of the condition in the first eye. In the rest the disease did not occur in the other eye in less than six years.

\section{Episcleritis}

Of patients with episcleritis, $36 \cdot 5$ per cent developed the condition in both eyes. When only one eye was affected there was no significant difference in the distribution between right and left eyes. Nodular disease occurred more commonly unilaterally than bilaterally. The fellow eye was affected either between one and three months or after six years. There were no exceptions to this in this series.

\section{Symptoms}

\section{REDNESS}

Almost all patients naturally presented with redness of the eyes. In simple episcleritis the onset was often extremely rapid, the eye becoming flushed within a few minutes of the onset of symptoms; in nodular episcleritis, scleritis, and diffuse anterior scleritis the onset was much more gradual, the intensity of the inflammation increasing over a period of several days. The redness was sectorial, ranging in intensity from the barely noticeable to the fiery red; the degree of inflammation bearing no relationship with the seriousness of the condition. Indeed, in scleromalacia perforans (necrotizing scleritis without surrounding inflammation) there might be no redness of the eye at all.

\section{LACRIMATION, PHOTOPHOBIA, AND CONJUNCTIVAL DISCHARGE}

Conjunctival discharge was not a feature of scleritis or episcleritis. Indeed, if the discharge is anything but watery in consistency an incorrect diagnosis has probably been made. Photophobia and lacrimation did not universally accompany episcleritis or scleritis, but where these symptoms were severe they often indicated the presence of a necrotizing process.

In scleritis these complaints were not universal; of the patients with diffuse anterior and nodular scleritis 27 per cent complained of some degree of watering. However, 70 per cent of the patients with necrotizing scleritis complained of photophobia and in 50 per cent the eye watered. Photophobia was unusual in posterior scleritis but about half the patients complained of some lacrimation. No correlation with the presence or type of keratitis could be demonstrated. The incidence of keratitis in each type of scleritis was much less than suggested by the symptoms of photophobia or lacrimation. In episcleritis when these symptoms occurred they were rarely, if ever, severe. Photophobia occurred in ro per cent of the patients and lacrimation was complained of in 25 per cent. Patients with nodular disease did not have more severe symptoms than those with simple episcleritis. Photophobia and lacrimation showed some correlation with corneal changes, but these symptoms were not always due to changes within the cornea.

PAIN

\section{Scleritis}

This is one of the very few severely painful eye conditions and severe pain was complained of in 60 per cent of these patients (Table II). The pain, which was boring in character, was either localized to the eye or generalized, in which case it radiated from the orbital margin to the temple or the jaw in the distribution of the trigeminal nerve. Some patients had been erroneously diagnosed as having migraine or sinusitis, and one patient was thought to have a cerebral tumour. Many other patients 
Table II Types of pain experienced in different types of scleritis (percentage)

\begin{tabular}{|c|c|c|c|c|}
\hline Type of scleritis & $\begin{array}{l}\text { Localized } \\
\text { only }\end{array}$ & $\begin{array}{l}\text { Generalized } \\
\text { only }\end{array}$ & $\begin{array}{l}\text { Both localized } \\
\text { and generalized }\end{array}$ & $\begin{array}{l}\text { Total no } \\
\text { of eyes }\end{array}$ \\
\hline Diffuse anterior & 14 & 15 & 30 & 119 \\
\hline $\begin{array}{l}\text { Nodular anterior } \\
\text { Necrotizing anterior }\end{array}$ & 25 & 16 & 20 & 134 \\
\hline $\begin{array}{l}\text { With inflammation } \\
\text { Without inflammation }\end{array}$ & ० & 15 & 46 & 29 \\
\hline (scleromalacia perforans) & $\circ$ & 13 & 19 & 13 \\
\hline Posterior & $\circ$ & 5 & 33 & 6 \\
\hline
\end{tabular}

suffered mild discomfort, but as this did not constitute one of their complaints these patients are not included in the table. Pain is rarely complained of in scleromalacia perforans, in which there is no surrounding inflammation; this is in marked contrast to the pain of necrotizing scleritis, which is the severest of all, often preventing sleep and causing severe loss of weight, and described by Mackenzie ( 1830 ) more than 140 years ago

['the pain . . . is pulsative and deep seated, the chief pain, however, is not so much in the eyeball, as round the orbit, under the eyebrow, and in the temple, cheek and side of the nose, and is severely aggravated from sunset to sunrise'].

The pain could indeed be so severe that the eye had to be removed.

\section{Episcleritis}

Severe pain is not a feature of episcleral involvement. Discomfort, rarely described as pain, occurred in $5 \mathrm{I}$ per cent of patients and was almost equally common in simple and nodular types. The sensation in the eye was described as hot, sharp, a slight ache, or irritable. Equally the pain around the eye was described as an ache and, although it sometimes radiated to the temple or jaw, it was never described as boring. However, very occasionally a patient will present with severe swelling of the lids, extreme discomfort, and even miosis and temporary myopia.

The pain or discomfort was localized to the eye in 25 per cent of those patients with simple episcleritis and 33 per cent of those with nodular episcleritis, and was felt around the eye but not in the eye itself in only 9 per cent of those with simple episcleritis and 14 per cent with nodular episcleritis. Both localized and generalized pain was experienced in 19 per cent in simple episcleritis and in 10 per cent in the nodular variety.

\section{Physical signs}

SCLERITIS

In the classification of scleritis which we have adopted it has been possible to distinguish each of the various types from their typical clinical appearances although, as already stated, while necrotizing scleral disease sometimes started as a nodular scleritis, its presence could usually be suspected because of the severity of the symptoms.

The essential diagnostic feature in scleritis was the involvement of scleral tissue in the inflammatory process. This usually took the form of scleral oedema which could be detected by observing the outward displacement of the deep vascular network of the episclera (Fig. 2).

Because the episclera was always swollen and congested in scleritis, scleral oedema was the sign which had to be looked for. The deep episcleral vascular plexus was more congested than the superficial network, giving rise to the typical bluish-red colour. The conjunctival vessels were rarely involved.

SCLERITIS-NODULAR ANTERIOR SCLERITIS (Fig. 3)

Although these patients resembled those with nodular episcleritis on cursory examination, detailed examination revealed marked differences and rarely presented any difficulty in diagnosis. The nodule was deep red in colour, totally immobile and quite separate from the overlying congested episcleral tissues. All the vessels were lifted by the nodule. There was, of course, some secondary overlying episcleritis and conjunctival congestion which involved the whole anterior episclera in 20 per cent (Fig. 3). Multiple nodules were seen in 42 per cent, sometimes reaching an enormous size; in 50 per cent they were tender.

\section{SCLERITIS-DIFFUSE ANTERIOR SCLERITIS (Fig. 4)}

This was the most benign form of scleritis and it was associated with the least severe of the associated general conditions. The patients might present with an eye in which the sclera was obscured by a diffuse redness and swollen episclera, which might be accompanied in severe cases by conjunctival oedema so severe as to obscure the cornea and protrude from between the eyelids. In these patients adrenaline $\mathrm{I}: 1000$ had to be applied to 


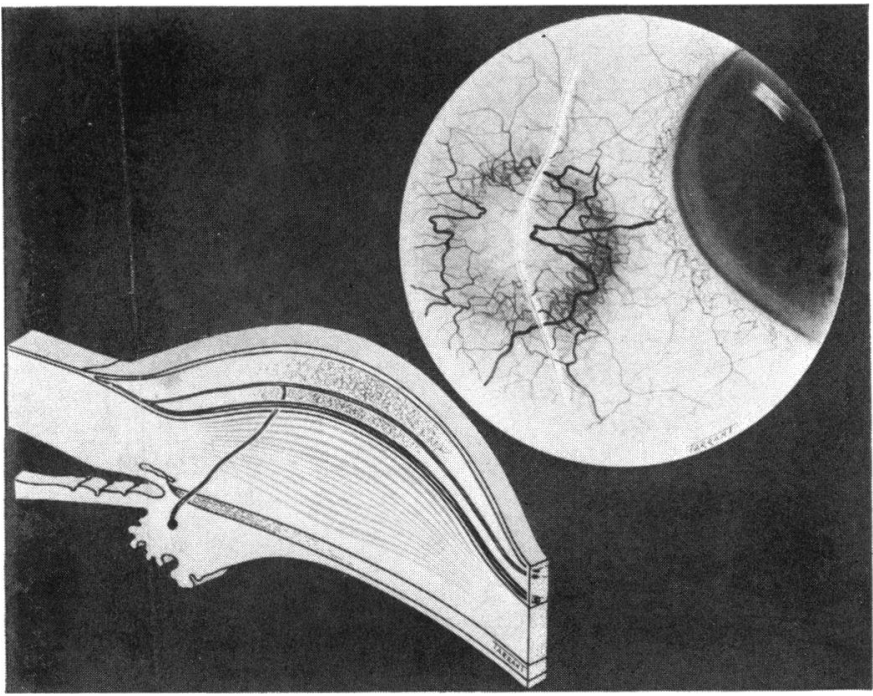

FIG. 2 Slit-lamp appearances in scleritis.

Sclera is swollen so that deep plexus of vessels is displaced forwards. Accompanying episcleritis causes slight separation of superficial networks

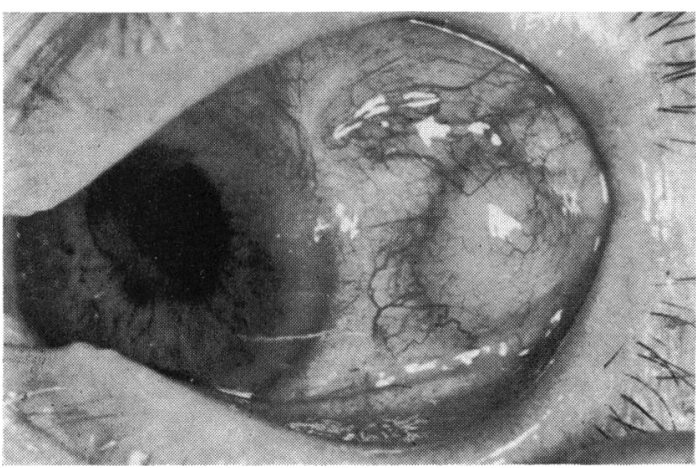

FIG. 3 Nodular anterior scleritis. $A$ discrete scleral nodule, displacement of deep vessels over nodule and surrounding inflammation overlying unaffected sclera are characteristic of this condition

the conjunctival sac so that the deep scleral network and the scleral tissue itself could be visualized, and any degree of scleral oedema determined. In the less severe cases the area of redness might be confined to a small area of the globe with very little overlying congestion. The inflammation was more widespread than in the nodular disease, and the extent of the involvement varied from a small area (6I per cent) to the whole anterior segment (39 per cent). The vascular pattern was occasionally grossly distorted and the normal radial pattern lost, with replacement of these vessels with abnormal tortuous new channels (Fig. 5). The eye was tender in 54 per cent of patients.

SCLERITIS-NECROTIZING SCLERITIS WITH SIGNS OF ADJACENT INFLAMMATION (Fig. 6)

This was found to be the most destructive form of the disease. Of these patients 60 per cent developed complications other than scleral thinning and 40 per cent suffered a deterioration of visual acuity. Those patients who were first seen at the onset of the disease presented with a localized patch of scleritis which was associated with acute congestion, sometimes so severe as to merit the term 'brawny' scleritis, but there was nothing in the physical appearances, the aetiology or prognosis, to justify including them as a separate category.

Another physical sign which must alert one to the presence of severe necrotizing scleral disease is the avascularity of a patch of episcleral tissue overlying or adjacent to an area of scleral oedema (Fig. 6). This sign was found in 27.5 per cent of

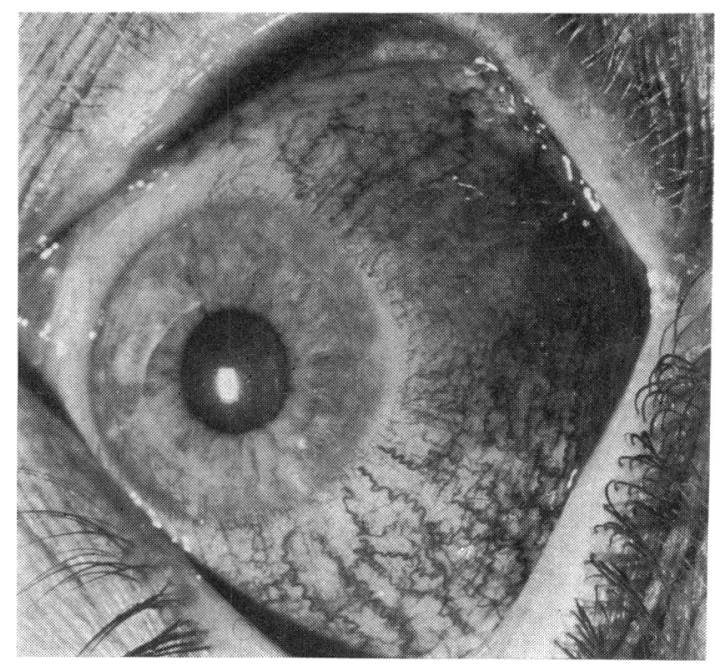

FIG. 4 Diffuse anterior scleritis. Underlying scleral oedema could be detected only by first blanching swollen congested episclera with $\mathrm{I}: 1000$ adrenaline 


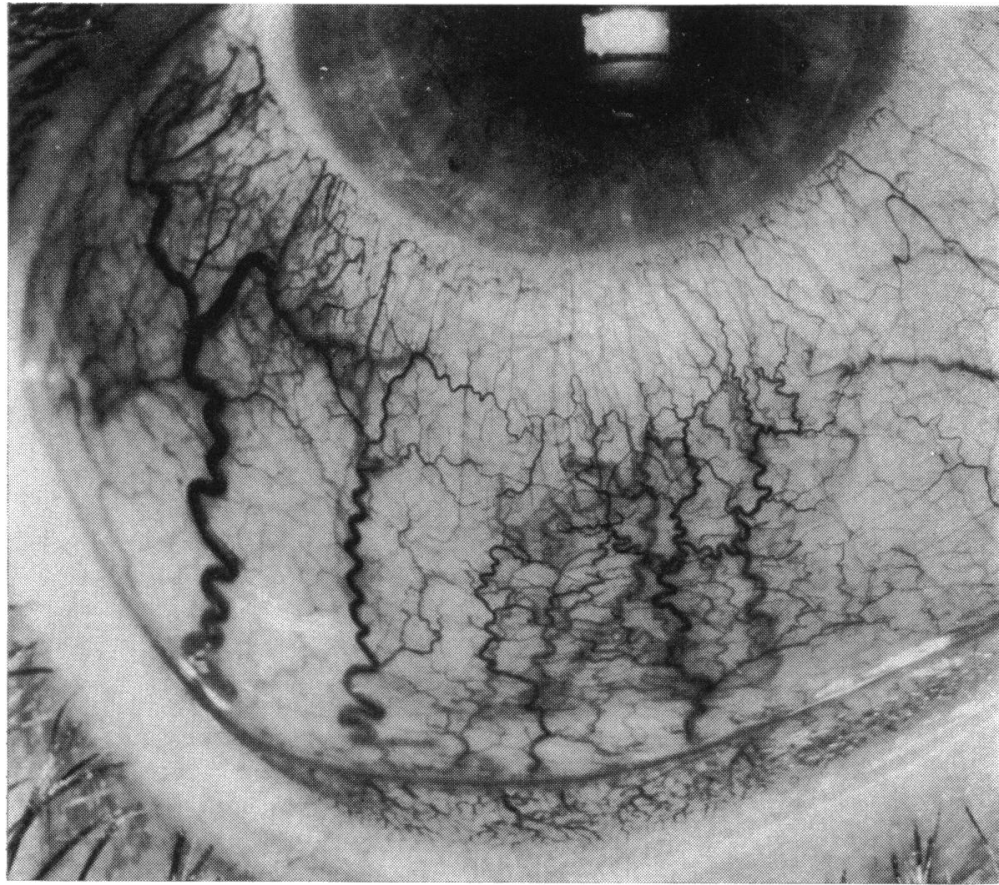

FIG. 5 Abnormal, tortuous vascular channels which develop after recurrent attacks of diffuse anterior scleritis

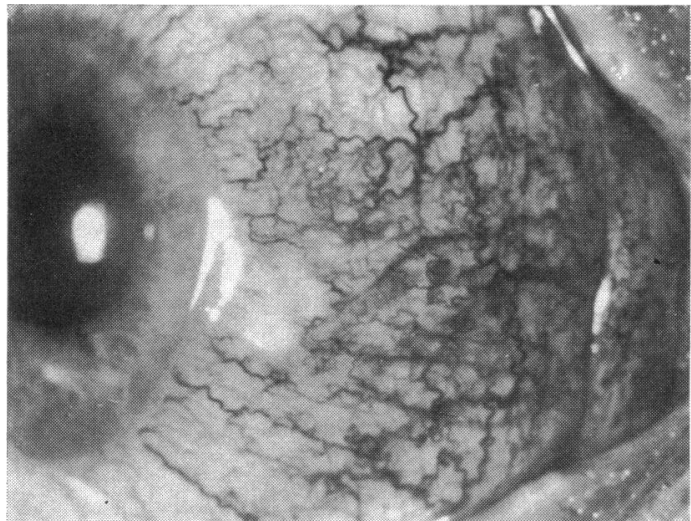

FIG. 6 Necrotizing anterior scleritis. Superficially this patient appears to be similar to those shown in Figs 4 and 5, but there is an avascular area adjacent to the limbus. If this is not treated, ulceration rapidly occurs similar to that in Fig. 7

patients with necrotizing scleritis with inflammation and in 23 per cent of those without inflammation (scleromalacia perforans).

Several types of response were noted. In some eyes the inflammation remained localized to one small area, and, if not checked by treatment, resulted in almost total loss of scleral tissue from that area. More frequently the inflammation started in one area and spread in both directions around the globe until the whole of the anterior segment had become involved (Fig. 7). When the inflammation subsided, or was suppressed by treatment, transparent sclera remained. Complications did not supervene until the inflammatory process had progressed through almost 360 degrees. Rarely the whole anterior segment became inflamed at one and the same time, and in some of these eyes areas of necrosis occurred which, if they had not been treated urgently, would have become sequestrated, exposing the underlying uvea. It was not, however, our experience that staphyloma (bulging of the

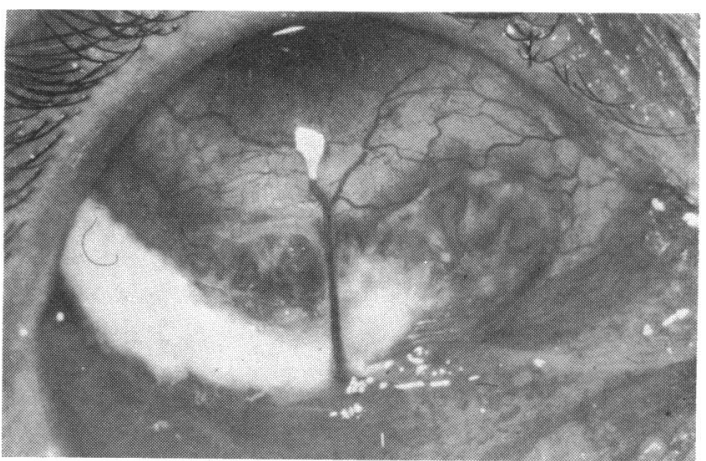

FIG. 7 Necrotizing anterior scleritis. Late stage of necrotizing scleritis. Inflammation is progressing around the globe, leaving an area of avascular necrotic sclera behind. Almost always these areas are crossed, as here, by a large vein which drains the limbal area on a thin bridge of normal sclera 
uvea into the scleral defect) occurred unless the intraocular pressure became raised above $30 \mathrm{mmHg}$ and had remained high for a prolonged period.

Avascularity of a patch of overlying sclera occurred in 27.5 per cent of the patients. These patches often occurred very early in the disease, and the condition must be treated vigorously if further necrosis is to be prevented. The eye was tender in 40 per cent of these patients.

\section{SCLERITIS-NECROTIZING SCLERITIS WITHOUT ADJACENT INFLAMMATION (SCLEROMALACIA PERFORANS) (Fig. 8)}

This condition was associated with long-standing rheumatoid arthritis in 46 per cent of patients. They presented without any subjective symptoms, the doctor or the patient having noticed either a greyish or yellowish patch on the sclera or, in more severe cases, areas of complete loss of tissue. Any inflammatory change was minimal. There was no reactive oedema because it appeared that the episcleral tissue overlying the defect had disappeared, and elsewhere it was so thin as to be almost invisible. The number of vessels in the remaining episcleral tissue also appeared to be much diminished, giving a porcelain-like appearance to the white of the eye when viewed from a distance. Altogether 40 per cent of the patients had more than one necrotic patch. We had the opportunity of watching some of these develop and the pattern seemed to be the same. The conjunctiva and remaining episclera might become suffused over a wide area or might remain unaltered. A demarcation line would develop in the sclera, like a circular crack, and the area inside this would take on a yellowish or greyish appearance and after a variable period would separate as a sequestrum together with the overlying episclera. Large abnormal vessels surrounded and crossed the area, and where they crossed it near the limbus they left an area of about $0.5 \mathrm{~mm}$ on either side of a relatively normal sclera. The resulting defect was covered by a very thin layer of connective tissue which appeared to be derived from the conjunctiva. Unless the intraocular pressure rose, no staphyloma was seen. In no case was the eve tender to the touch.

\section{SCLERITIS-POSTERIOR SCLERITIS}

We were certain of the diagnosis in six cases (2.9 per cent), but it was suspected in several cases, and it was likely that others escaped our notice. Since there are no apparent external signs of posterior scleritis unless there is also an associated anterior scleritis, the presence of proptosis, exudative detachment and other fundus changes, including papilloedema, may mislead the ophthalmologist to such an extent that the correct diagnosis is never made. In view of this it is possible that the incidence of posterior scleritis may not be as low as indicated by the present series, as our patients were all referred from elsewhere. The condition was unilateral in four of the six cases.

\section{PRESENTING FEATURES IN POSTERIOR SCLERITIS}

Symptoms. In all the patients there was extreme pain and tenderness.

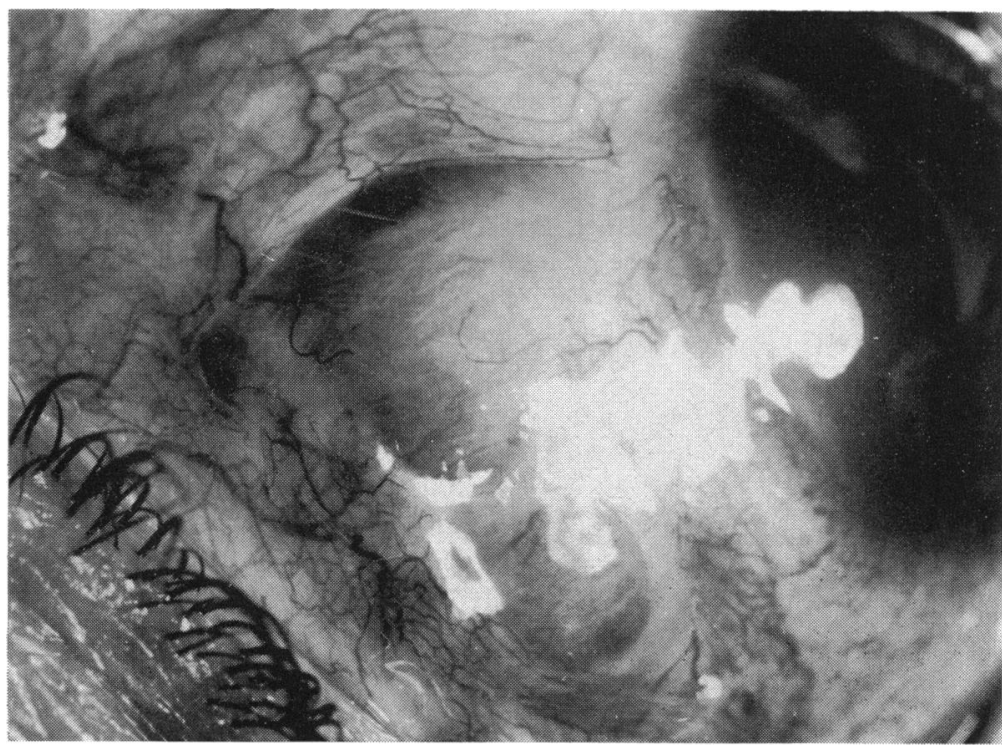

FIG. 8 Necrotizing scleritis without inflammation (scleromalacia perforans). Almost complete dissolution of scleral collagen occurring with little if any surrounding inflammation in woman of 60 years with long-standing rheumatoid arthritis 


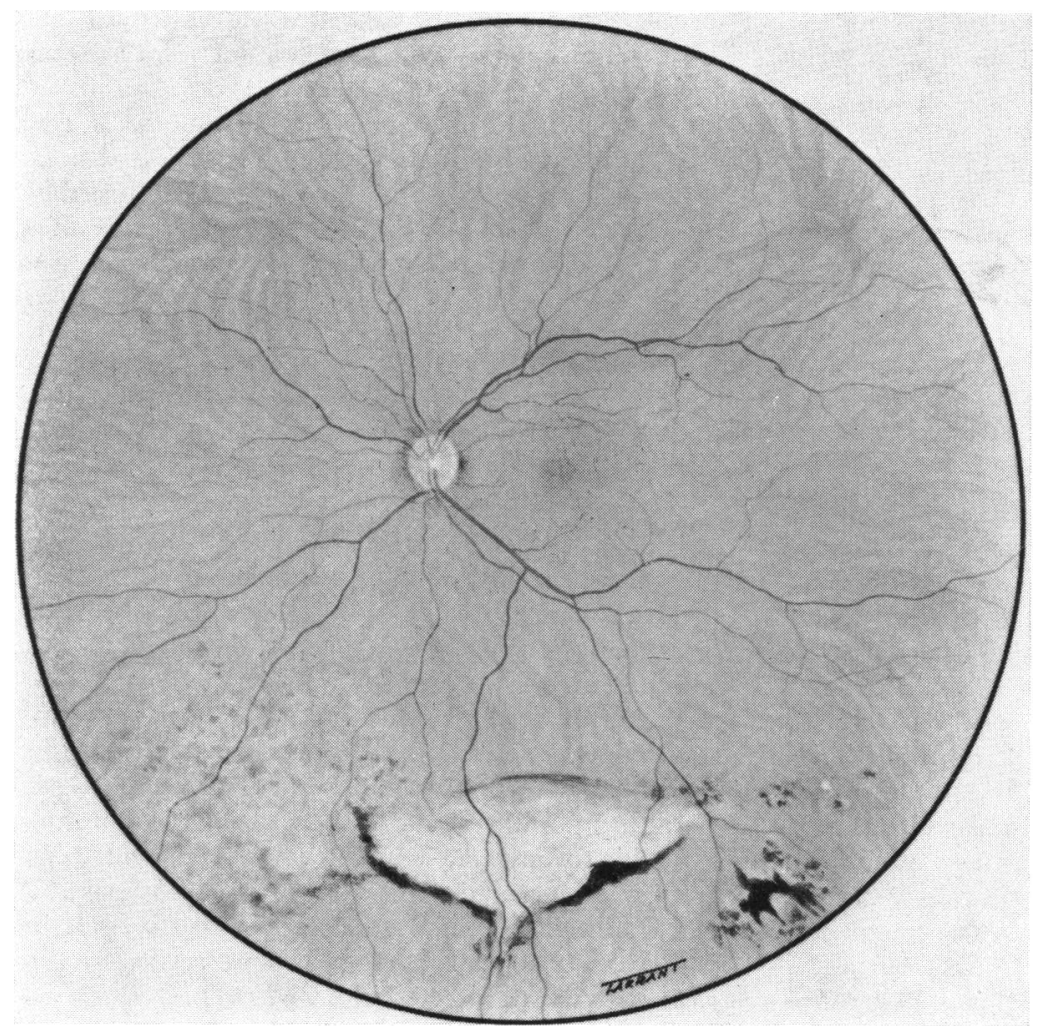

FIG. 9 Appearance of fundus after resolution of extensive serous detachment in patient with posterior scleritis who presented with diminution of vision, anterior scleritis, slight proptosis, and a diffuse leak early in dye transit on fluorescein angiography

Visual acuity. All eyes except one showed some reduction in visual acuity.

Fundus changes. In four of these patients there was an exudative retinal detachment associated with swelling of the optic disc and an anterior diffuse scleritis. The anterior scleral involvement was minimal and had to be looked for carefully, but the retinal changes were typical. Areas of exudation occurred beneath the retina, giving the appearance of pale greyish-white spots with a surrounding dark greyish line that could be seen through the overlying serous detachment (Fig. 9).
In the early stages there was a diffuse leak early in the dye transit on fluorescein angiography.

Proptosis. Two patients presented with proptosis, a diffuse anterior scleritis, limitation of ocular movements, especially upwards, and retraction of the lower lid (Fig. Io) when attempting to look upwards. This physical sign seemed to be specific for this condition and was presumably caused by infiltration of both the tendons and the muscle cone in the region of the posterior scleritis. Diplopia was also a presenting feature of posterior scleritis because of involvement of the muscles and tissues

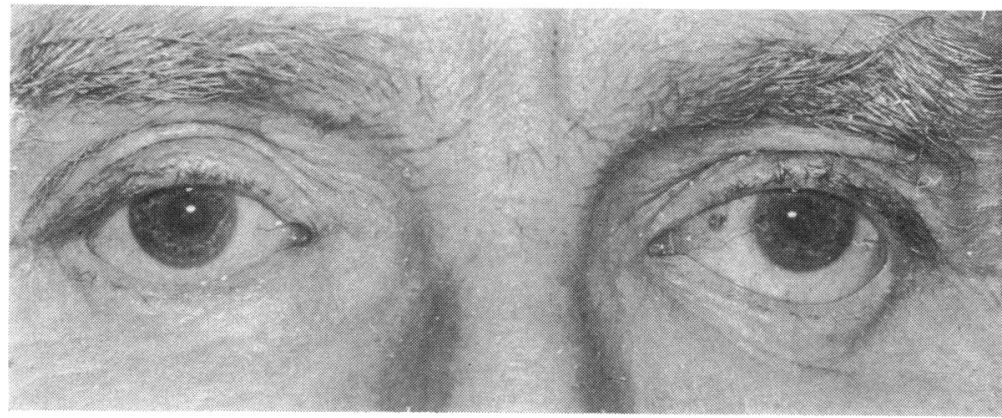

FIG. Io Posterior scleritis. Retraction of left lower lid in patient with posterior scleritis who also had severe limitation of ocular movements. Ocular movements became normal with treatment but the lid sign remained 
within the muscle cone by the inflammatory process. All these features returned to normal after treatment. The exudative detachment in one patient disappeared within five hours of starting treatment. The site of inflammation remained pale and white after the inflammation had disappeared, leaving some areas of pigment migration at the edges, giving the appearance of a high-water mark.

\section{EPISCLERITIS}

Simple and nodular episcleritis differed in their clinical signs, but in both, the oedema or infiltration were entirely within the episcleral tissue; the sclera itself was not involved. The episcleral vascular network was maximally congested, with some congestion of the conjunctival vessels and minimal congestion of the scleral vessels (Fig. II).

\section{EPISCLERITIS-SIMPLE EPISCLERITIS}

The redness of the episclera was often very intense and was localized to one sector in 69 per cent of patients and generalized in 31 per cent. The episcleral vessels, although engorged, retained their normal radial position and architecture. The colour varied from fiery red to a mild red flush but did not have the bluish hue so typically seen in scleritis.

In simple episcleritis there was a diffuse oedema of the episcleral tissue which was sometimes infiltrated by greyish deposits which appeared yellowish in red-free light. The depth of the oedema and its effect on the vascular plexus was best recognized by slit-lamp examination, using a narrow beam. The eye was tender to the touch in 33 per cent of cases.

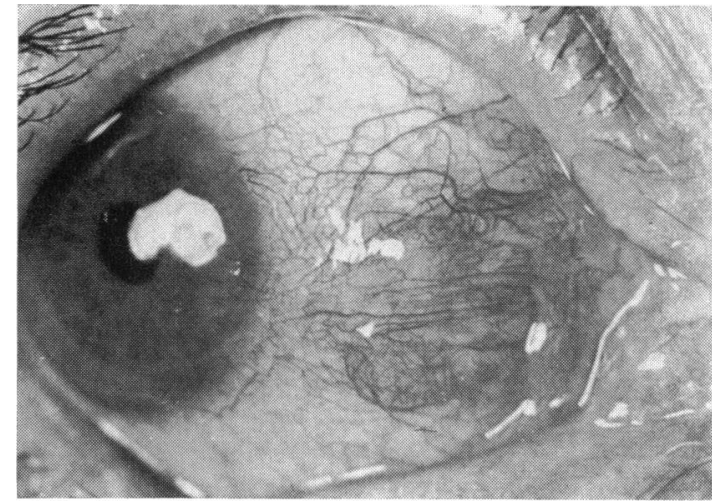

FIG. 12 Nodular episcleritis. Swelling and oedema confined to episcleral tissue and vessels retain their normal architecture

\section{EPISCLERITIS-NODULAR EPISCLERITIS}

In contrast with simple episcleritis the oedema and infiltration of nodular episcleritis were localized to one part of the globe, except in seven eyes in which the redness was widespread. A nodule from within the episcleral tissue, which was surrounded by some congestion, was mobile on the underlying sclera and there was no involvement of the sclera in the oedema. The scleral plexus of vessels could be distinguished deep to the nodule lying flat on the sclera, which retained its normal contour (Figs II and 12). The nodules were usually single but were sometimes multiple, reaching the size of a large pea. The eye was tender to the touch in 40 per cent.

\section{Vascular changes in the episclera}

Although vascular changes were most unusual in episcleritis, vessels that appeared to be abnormal

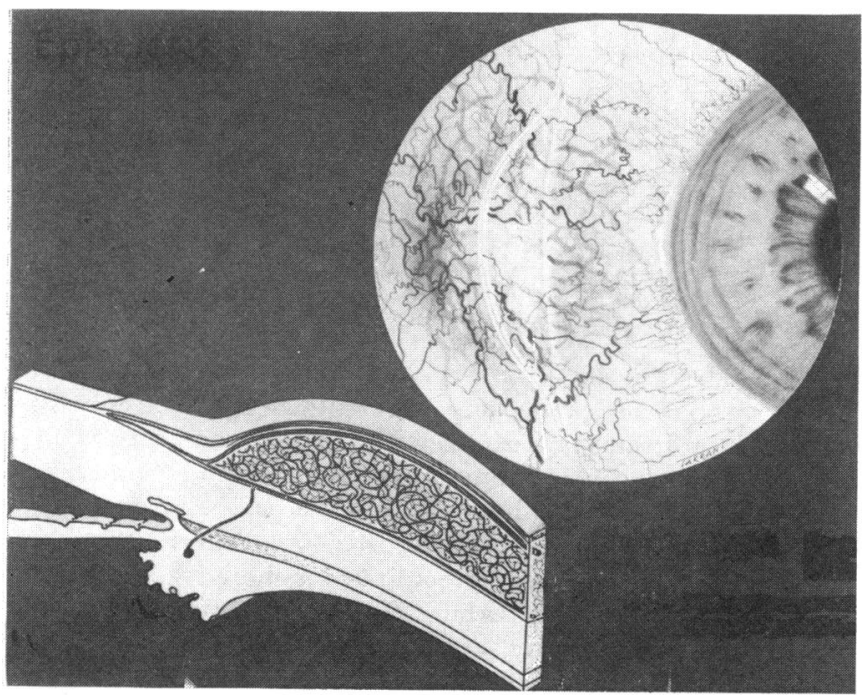

FIG. I I Episcleritis. Although deep vascular network is congested there is no scleral swelling, oedema and infiltration being confined to episclera 
either in course or type were noted in 19 eyes with simple episcleritis and 1o eyes with nodular episcleritis. All these patients had had recurrent attacks at the same site for many years. One patient showed avascularity of the episcleral nodule which was thought to be due to the intensity of the oedema, as the vessels returned to normal as soon as treatment was given.

\section{Complications}

Complications of some sort were found in only I 5 per cent of patients with episcleritis but ocular complications, other than simple increased scleral transparency or thinning, occurred in 57 per cent of all patients with scleritis. The complications looked for and analysed were:

I. Fall in visual acuity

2. Keratitis

3. Cataract

4. Uveitis

5. Glaucoma

6. Scleral thinning (and scleral defects)

\section{Fall in visual acuity}

\section{SCLERITIS}

A total of 42 eyes ( 14 per cent) in patients with scleritis lost a significant amount of vision after the disease had been present for one year. This fall in visual acuity was attributed to cataract (five eyes), anterior uveitis (two eyes), and posterior uveitis (two eyes). The commonest reason for the fall in visual acuity was the association with keratitis (Table IV), particularly if this was accompanied by a uveitis.

\section{EPISCLERITIS}

No patient with episcleritis had a fall in visual acuity during the period of follow-up.

Table III Fall of visual acuity in scleritis

\begin{tabular}{|c|c|c|}
\hline Type of scleritis & $\begin{array}{l}\text { Total } \\
\text { no. of } \\
\text { eyes }\end{array}$ & $\begin{array}{l}\text { Fall in visual acuity } \\
2 \text { lines or more during } \\
\text { period of follow-up } \\
\text { (per cent) }\end{array}$ \\
\hline Diffuse anterior & II 9 & I 5 \\
\hline $\begin{array}{l}\text { Nodular anterior } \\
\text { Necrotizing anterior }\end{array}$ & 134 & 7 \\
\hline $\begin{array}{l}\text { With inflammation } \\
\text { Without inflammation } \\
\text { (scleromalacia }\end{array}$ & 29 & 27 \\
\hline $\begin{array}{l}\text { perforans) } \\
\text { terior }\end{array}$ & $\begin{array}{r}13 \\
6\end{array}$ & 31 \\
\hline
\end{tabular}

Table IV Fall of visual acuity in scleritis due to keratitis

\begin{tabular}{ll}
\hline Keratitis & $\begin{array}{l}\text { No. of eyes with fall in visual acuity } \\
\text { during follow-up }\end{array}$ \\
\cline { 1 - 1 } Superficial & 2 \\
Midstromal & 3 \\
Deep & 0 \\
Guttering & 3 \\
Others & 5 \\
\hline
\end{tabular}

\section{Keratitis}

SCLERITIS

Corneal changes of a type characteristically seen in scleritis were observed in 29 per cent of patients. This keratitis can be serious, leading to permanent changes in the cornea; these are so characteristic that when certain types of sclerosing keratitis and lipid changes are seen in an eye which is otherwise normal, it can be inferred that the patient has had scleritis at some time in the past.

Characteristic corneal changes were seen in each type of anterior scleritis and could be classified as follows:

\section{Nodular scleritis}

i. Localized stromal keratitis

ii. Localized sclerosing keratitis

\section{Diffuse scleritis}
i. Acute stromal keratitis
ii. Sclerosing keratitis
iii. Corneal guttering

\section{Necrotizing scleritis}
i. Sclerosing keratitis
ii. Keratolysis

The incidence of keratitis in different types of scleritis is given in Table $\mathrm{V}$.

\section{Acute stromal keratitis (Fig. 13)}

In the severe necrotizing scleritis of acute onset the cornea became oedematous and dense white infiltrates appeared within the stroma (Fig. 13). These were sometimes central and sometimes peripheral and might coalesce as the disease progressed. If, in addition, there was anterior chamber activity, keratic precipitates adhered to the posterior corneal surface. The opacity was sometimes surrounded by a 'precipitin' ring. If the scleritis was treated vigorously with full doses of steroids 
Table $\mathrm{V}$ Keratitis and vascularization of the cornea in scleritis

\begin{tabular}{|c|c|c|c|c|c|c|c|c|c|c|}
\hline \multirow[b]{2}{*}{ Type of scleritis } & \multirow{2}{*}{$\begin{array}{l}\text { Total } \\
\text { no. of } \\
\text { eyes }\end{array}$} & \multicolumn{5}{|c|}{ Keratitis } & \multicolumn{4}{|c|}{ Corneal vascularization } \\
\hline & & $\begin{array}{l}\text { Super- } \\
\text { ficial }\end{array}$ & $\begin{array}{l}\text { Mid- } \\
\text { stromal }\end{array}$ & Deep & $\begin{array}{l}\text { Gutter- } \\
\text { ing }\end{array}$ & Other & $\begin{array}{l}\text { Super- } \\
\text { ficial }\end{array}$ & $\begin{array}{l}\text { Mid- } \\
\text { stromal }\end{array}$ & Deep & Other \\
\hline Diffuse anterior & 119 & 8 & 10 & 2 & 4 & 4 & 3 & 2 & 3 & 2 \\
\hline $\begin{array}{l}\text { Nodular anterior } \\
\text { Necrotizing anterior }\end{array}$ & 134 & 6 & 14 & 4 & 5 & 6 & 5 & 0 & I & $\circ$ \\
\hline $\begin{array}{l}\text { With inflammation } \\
\text { Without inflammation }\end{array}$ & 29 & 4 & 4 & 2 & 4 & 3 & 2 & $\mathbf{I}$ & 3 & $\circ$ \\
\hline (scleromalacia perforans) & 13 & $\circ$ & 3 & $\mathbf{I}$ & 3 & $\circ$ & $\mathbf{I}$ & 3 & 2 & I \\
\hline Posterior & 6 & 0 & 0 & $\mathbf{I}$ & 0 & $\circ$ & ○ & 0 & ○ & 0 \\
\hline Total & 301 & 18 & $3 \mathbf{I}$ & Io & 16 & 13 & I I & 6 & 9 & 3 \\
\hline
\end{tabular}

these opacities could disappear without trace. More usually, however, linear opacities within the stroma remained and, if central, these impaired vision.

\section{Sclerosing keratitis (Fig. 14)}

The corneal opacities associated with scleral disease usually appeared less dramatically; the cornea adjacent to the swollen sclera became oedematous and vessels grew into this oedematous area. Vascularization never seemed to precede the oedema. Although these opacities usually occurred close to the limbus they could appear in the superficial and midstroma centrally in the cornea, having no obvious connexion with the site of the scleral disease.

Whatever the type or site of the corneal lesion, treatment of the scleritis brought about resolution of the keratitis which might be complete or, more usually, the lamellae of the cornea were altered to leave thin linear opacities which looked exactly like the sugar crystals of 'candy floss' (Fig. 14). Crystalline (candy-floss) opacities were seen in 23 patients with diffuse and another 23 patients with nodular scleritis, and five patients with necrotizing scleral disease. This type of corneal change could not be correlated with vascularization or any particular aetiological agent. Keratolysis was observed in four patients, all of whom had severe necrotizing anterior scleritis. These opacities, once formed, never disappear. In very severe cases the opacification of the cornea progressed circumferentially until only a central clear area in the cornea remained, and even this area might disappear, resulting in a 'scleralized cornea'. Corneal grafting was very successful in restoring the visual acuity in these patients.

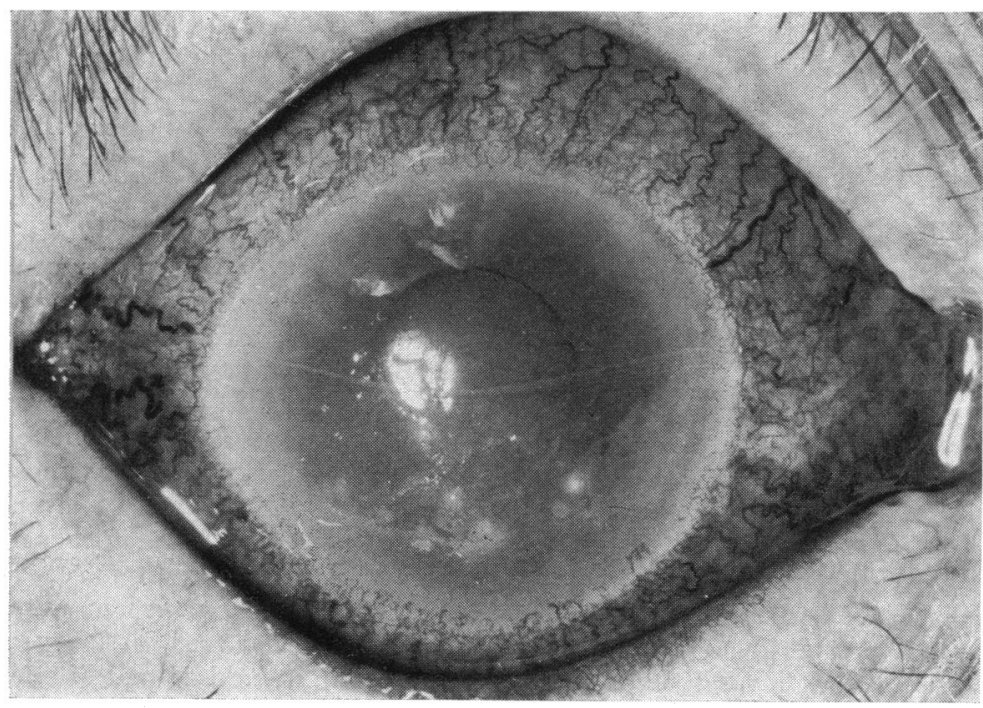

FIG. 13 Acute stromal keratitis in scleritis. Dense white infiltration in cornea in same patient as in Fig. 9. Immune rings similar to those seen in Fig. 14 appeared round these lesions. All corneal signs, etc. disappeared after treatment 


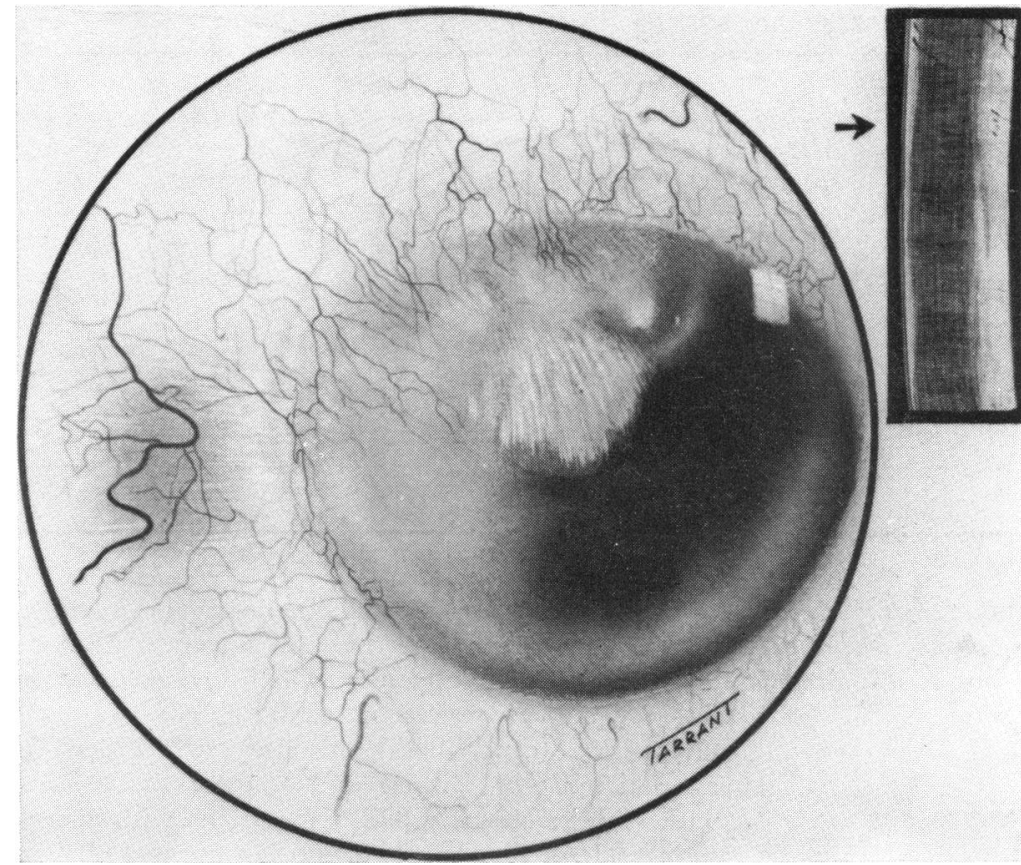

FIG. 14 Sclerosing keratitis in scleritis. A 66-year-old woman with a 13-year history of recurrent bilateral diffuse sclero-keratitis with crystalline (candy-floss) deposits in the deep stroma and a 'precipitin ring' around the infiltration at 12.0 o'clock. The vascularization is passive. Vessels enter the cornea only at site of advancing edge of corneal change and at late stage in disease. Acute stromal keratitis will progress to this if left untreated

\section{Limbal guttering}

Guttering of the peripheral cornea was not infrequently seen, particularly in patients who had severe long-standing rheumatoid arthritis. These gutters never extend more than $2 \mathrm{~mm}$ from the limbus, but may become circumferential and very thin, requiring grafting. Erosion of the deep stroma resembling Terrien's disease may also occur, and in one case this led to an expansion of the eye to 18 dioptres of astigmatism in that axis, necessitating corneo-scleral grafting over the affected region (Fig. I5).

\section{Keratolysis}

The most severe corneal disease of all is keratolysis. This was seen in only four patients, all of whom had very severe necrotizing scleritis, usually, but not invariably, accompanied by loss of scleral tissue. In this terrifying situation the whole stroma of the cornea disappeared with alarming rapidity (Fig. I6). The progress could have been stopped by full steroid therapy but only after very prolonged treatment would any corneal tissue have been re-formed. It was usual therefore to graft these eyes when the scleritis had become well controlled or if rupture appeared imminent.

Lipid deposition occurred in areas where the cornea had been damaged and at the inner edge of a long-standing corneal gutter. This was presumably because of interference with the usual flow of these metabolites to the limbus and it was not a product of the corneal inflammation.

\section{Posterior corneal changes}

Although we have not analysed this series for it, we have recently come to recognize another pattern of corneal change in scleritis (Holt-Wilson and Watson, 1974), which presented as an interstitial keratitis indistinguishable from that seen in congenital syphilis but which occurred in patients who had a mild scleritis and in whom the serological investigations were entirely negative (Fig. I7).

Keratitis could be considered the sole reason for a severe fall in visual acuity in 13 eyes (4 per cent).

\section{EPISCLERITIS}

Minimal corneal changes were seen in 15 per cent of the patients with simple episcleritis and in 15 per cent of those with nodular disease, but these were never severe. The oedema of the cornea occurred when the episcleral inflammation was close to the limbus and seemed to be a consequence of this adjacent inflammation. Keratitis was most common in the superficial and midstromal layers of the cornea in both varieties. Some localized corneal guttering occurred in six eyes after recurrent attacks in the same area for many months. Vascularization of the cornea occurred in six eyes, the vessels being deep in three, midstromal in one, 


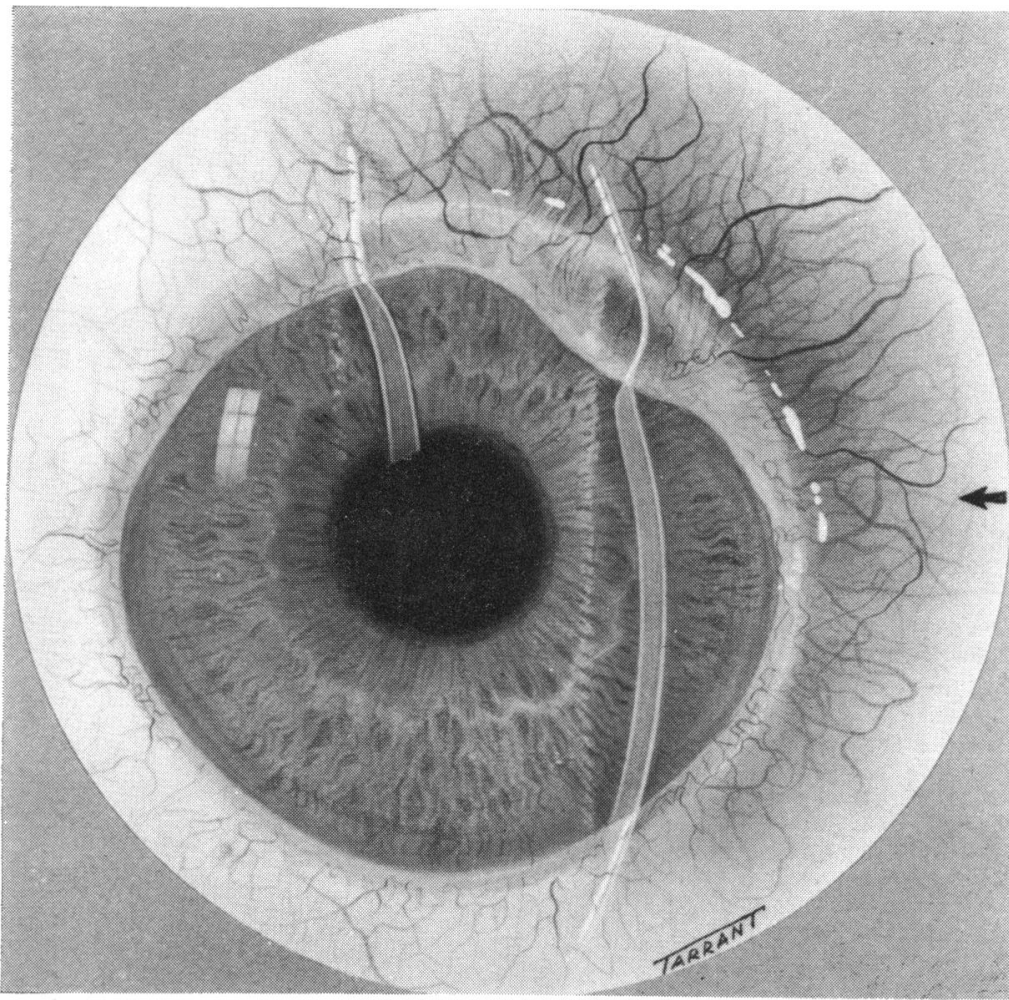

FIG. 5 Limbal guttering in scleritis. A 24-year-old man with a ro-year history of unilateral scleritis localized to area of sclera between 12.0 and 2.0 o'clock. Cornea in area has become guttered and produced a 'Terrien'-like change. This area required grafting (Fig. 19) because of rapidly increasing expansion of globe in this axis

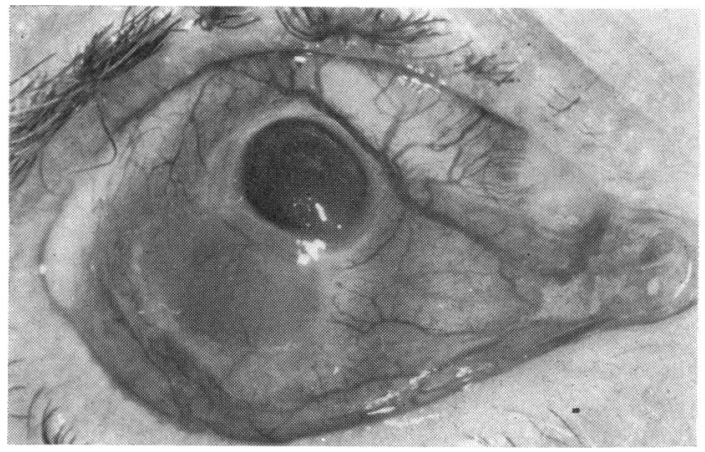

FIG. 16 Keratolysis. Severe necrotizing changes in both cornea and sclera which occurred in a period of five weeks in a 74-year-old woman. Systemic steroids suppressed inflammation and both cornea and sclera were grafted successfully

and superficial in two. No serious complications were found in any of the patients studied.

\section{Cataract}

\section{SCLERITIS}

Cataracts were detected in only 22 eyes, 7 per cent. These were bilateral and senile in type in 15 eyes. In 12 eyes the cataract was noted to have become worse during the course of the disease. All these patients were between the ages of 55 and 80 years and all had serious scleral disease. In only three patients (five eyes) with an associated longstanding anterior uveitis was it felt certain that the sclero-uveitis was responsible for the cataracts. In two of these patients it was particularly noticeable that the cataract had developed rapidly once the scleritis had involved the sclera through $360^{\circ}$. Three of these cataracts have required extraction. The sclero-corneal wound has healed normally after cataract extraction in spite of continuing active scleritis in the area of the wound. One eye developed a steroid-induced cataract after

Table VI Keratitis in episcleritis

\begin{tabular}{|c|c|c|c|c|}
\hline \multirow{2}{*}{ Episcleritis } & \multicolumn{4}{|c|}{ Type of keratitis } \\
\hline & Superficial & $\begin{array}{l}\text { Mid- } \\
\text { stromal }\end{array}$ & Deep & Guttering \\
\hline Simple & 7 & 14 & 3 & 5 \\
\hline Nodular & 2 & 4 & $\mathbf{I}$ & $\mathbf{I}$ \\
\hline vascularization & 2 & $\mathbf{r}$ & 3 & 0 \\
\hline
\end{tabular}




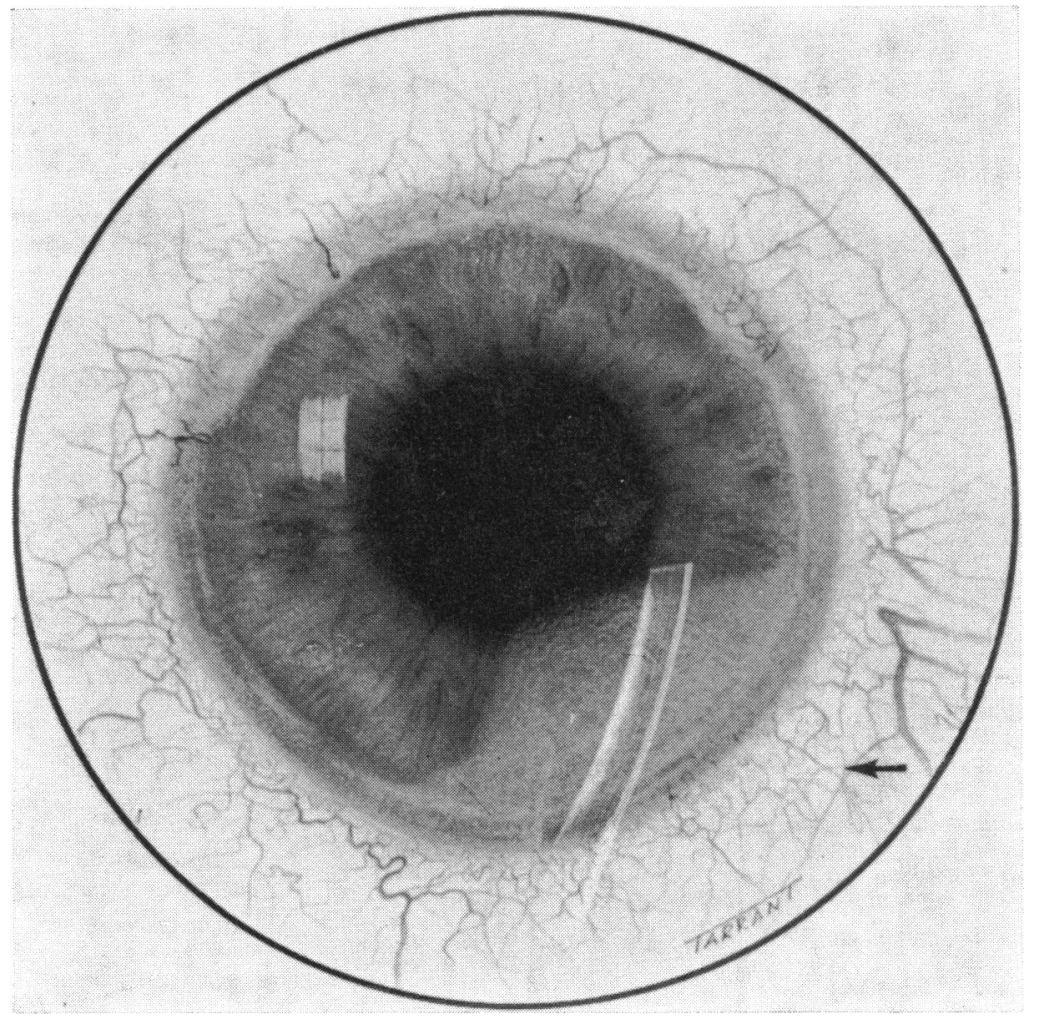

FIG. I7 Deep stromal corneal changes as seen in group of young patients with diffuse anterior scleritis. When vessels enter cornea they do so adjacent to Descemet's membrane, giving the appearance of a syphilitic interstitial keratitis

prolonged local steroid treatment. Five eyes in which cataract developed also showed a severe long-standing anterior uveitis.

\section{EPISCLERITIS}

Eight patients, six of whom were over 60 years old, were found to have cataracts. However, in none of these patients did the cataract progress during the period of follow-up, nor were the cataracts worse in the eyes with episcleritis. One patient had developed a typical steroid cataract from prolonged local steroid treatment before we saw him. No correlation was found between episcleritis, uveitis, or cataract.

\section{Uveitis}

SCLERITIS

\section{Anterior uveitis}

There was evidence of anterior uveitis in 30 per cent of all the eyes with scleritis. It was found universally in those patients with scleromalacia perforans (Table VII). However, it did not always occur in those with necrotizing scleritis, nor was there any particular correlation between the presence of an anterior uveitis with any particular disease. When an anterior uveitis did occur it tended to be longstanding and intractable.

The distribution was evenly divided between unilaterally and bilaterally affected eyes. Only two patients developed a uveitis in the other, apparently unaffected, eye.

\section{Posterior uveitis}

All the patients with posterior scleritis had posterior uveitis, but posterior uveitis was also found in those who had an anterior scleritis (Table VIII).

In two of the patients with nodular anterior scleritis, and in three of those with necrotizing disease, discrete areas of subretinal exudation

Table VII Anterior uveitis in scleritis

\begin{tabular}{lrll} 
Type of scleritis & Eyes & & $\begin{array}{l}\text { Anterior uveitis } \\
\text { (per cent) }\end{array}$ \\
\cline { 1 - 1 } Anterior & & \\
Diffuse & 119 & & 35 \\
Nodular & 134 & & 17 \\
Necrotizing & 29 & & 37 \\
Scleromalacia perforans & 13 & 100 \\
Posterior & 6 & 66 \\
\hline
\end{tabular}


Table VIII Posterior uveitis in scleritis

\begin{tabular}{lrcc}
\hline Type of scleritis & Eyes & & $\begin{array}{l}\text { Posterior uveitis } \\
\text { (per cent) }\end{array}$ \\
\cline { 1 - 1 } Anterior & & \\
$\quad$ Diffuse & 119 & 13 \\
Nodular & 134 & 3 \\
Necrotizing & 29 & 17 \\
Scleromalacia perforans & 13 & 23 \\
Posterior & 6 & 100 \\
\hline
\end{tabular}

could be seen at the periphery of the fundus with a 'high-water mark' of retinal and subretinal oedema around the patches of exudation. One patient developed an annular choroidal detachment at the height of the scleritis.

\section{EPISCLERITIS}

No severe uveitis occurred in this series. Mild uveitis, detectable on the slit-lamp by an increase in the number of cells in the anterior chamber and a mild aqueous flare, was found in 12 eyes. In two unilateral cases, flare and cells were noted in the unaffected eye. No correlation between corneal involvement and uveitis was detected.

\section{Glaucoma}

\section{SCLERITIS}

Glaucoma was present in 35 eyes ( 116 per cent), of which 20 per cent showed associated keratitis.

Of the patients with secondary glaucoma nine had no abnormality other than scleritis, seven also had keratitis, and six uveitis.

Secondary glaucoma often accompanies severe anterior scleritis, the cause apparently being due to obstruction of the outflow channels by oedema because the intraocular pressure falls and the outflow of aqueous rises as soon as the scleritis comes under control with systemic treatment. Six patients, who had anterior synechiae and a long-standing uveitis with secondary glaucoma, required other medication for control of the intraocular pressure. None of these patients has yet required surgery.

No patient with posterior scleritis had glaucoma.

One patient developed a steroid glaucoma which has required continuous medication for its control.

\section{EPISCLERITIS}

Glaucoma was detected in nine eyes (4 per cent). Two patients were known to have chronic openangle glaucoma before the onset of the episcleritis. Five eyes had developed a steroid glaucoma from prolonged administration of local steroids. In no instance could the glaucoma be attributed to the episcleral inflammation, although there was corneal involvement in one eye.

\section{Scleral thinning}

When the sclera looked blue in the daylight when contrasted with surrounding white sclera this was regarded in our analysis as scleral thinning. The sclera in many of these patients had become transparent rather than thin; however, the blue patch appeared only in cases in which there had been active disease. The change in transparency was usually not apparent during the active stage of the disease but it was observed at the site of recurrent simple or nodular episcleritis in 19 eyes ( 8 per cent), and in 36.5 per cent of eyes affected with scleritis, during the period of follow-up.

After repeated attacks of episcleritis, particularly if these occurred at the same site, the sclera might become transparent but not thin. Similarly in diffuse and nodular scleritis the sclera might become transparent with the blue choroid showing through. This was easily seen in daylight and could be used as an indication of previous scleral inflammation. Ectasia and destruction of scleral tissue occurred only in necrotizing scleritis. This could take the form of an avascular area appearing in the centre of an area of scleritis, which then broke down to form a slough and eventually to leave an area of thinning.

Table IX Glaucoma in scleritis

\begin{tabular}{|c|c|c|c|c|c|c|}
\hline Type of scleritis & Total & $\begin{array}{l}\text { Total with } \\
\text { glaucoma }\end{array}$ & $\begin{array}{l}\text { Primary } \\
\text { open-angle }\end{array}$ & $\begin{array}{l}\text { Primary } \\
\text { closed-angle }\end{array}$ & Secondary & $\begin{array}{l}\text { Steroid- } \\
\text { induced }\end{array}$ \\
\hline Diffuse anterior & II 9 & 12 & 6 & ○ & 6 & o \\
\hline Nodular anterior & 134 & II & 6 & o & 5 & $\circ$ \\
\hline Necrotizing anterior & 29 & 8 & 2 & 0 & 5 & $\mathbf{I}$ \\
\hline Scleromalacia perforans & 13 & 4 & 0 & 0 & 4 & 0 \\
\hline \multirow[t]{2}{*}{ Posterior } & 6 & 0 & 0 & ○ & 0 & 0 \\
\hline & 301 & 35 & 14 & 0 & 20 & $\mathbf{I}$ \\
\hline
\end{tabular}


Table X Scleral thinning or transparency in scleritis

\begin{tabular}{|c|c|c|c|c|}
\hline \multirow[b]{2}{*}{ Type of inflammation } & \multirow[b]{2}{*}{$\begin{array}{l}\text { Total no. } \\
\text { of eyes }\end{array}$} & \multicolumn{3}{|c|}{ Eyes with thinning } \\
\hline & & Localized & Generalized & $\begin{array}{l}\text { Total incidence } \\
\text { (per cent) }\end{array}$ \\
\hline \multicolumn{5}{|l|}{ Episcleritis } \\
\hline Simple & 170 & 12 & 3 & 9 \\
\hline Nodular & 47 & 4 & 0 & 9 \\
\hline \multicolumn{5}{|l|}{ Scleritis } \\
\hline Diffuse anterior & II9 & 23 & I 5 & 32 \\
\hline Nodular anterior & 134 & 35 & 2 & 28 \\
\hline Necrotizing anterior & 29 & I I & 10 & 69 \\
\hline Scleromalacia perforans & 13 & 7 & 6 & 100 \\
\hline Posterior & 6 & I & o & 16 \\
\hline
\end{tabular}

In the type of necrotizing scleritis which progressed around the globe, the area behind the advancing edge could become extremely thin, and sometimes melted away altogether. In the variety of necrotizing scleritis without inflammation (scleromalacia perforans), the episclera was usually extremely thin (Fig. 8), and the underlying sclera would become white, develop a demarcated margin, and then become sequestrated. The conjunctiva and thin episclera overlying this process might be slightly congested but this was by no means always the case. A combination of A- and B-scan ultrasound could be used to distinguish between thinning and increased transparency-A-scan being used to estimate the thickness and $\mathrm{B}$ to locate the lesion.

\section{Scleral defects (Fig. I8)}

Scleral defects, as opposed to scleral thinning or increased scleral transparency, were seen only in the severest forms of necrotizing disease. When the

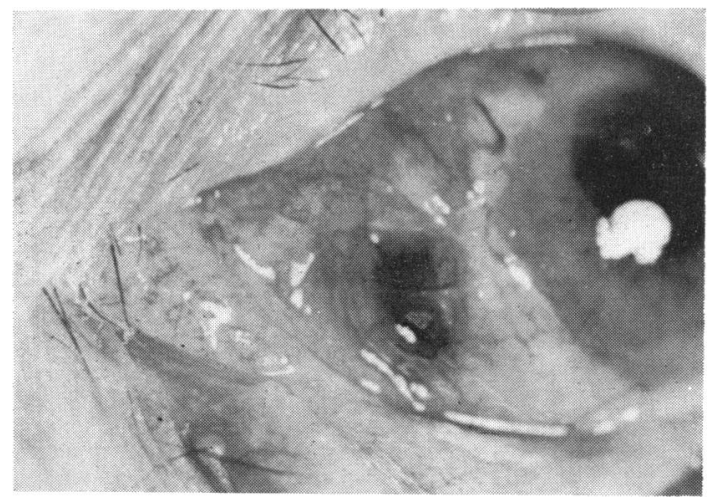

FIG. 18 Scleral defect. Scleral defect occurring in patient with severe necrotizing scleritis. Ciliary body is exposed but no staphyloma occurs unless intraocular pressure rises above $40 \mathrm{mmHg}$ necrotizing disease was associated with inflammation, the episclera became avascular, overlying the area which would eventually become sequestrated. Treatment at this stage would prevent sequestration. In scleromalacia perforans sequestration might take place without any warning. The loss of tissue in either condition might involve only a part of the scleral thickness.

Sequestration occurred in 22 eyes ( 7 per cent). Loss of tissue took place in 4I per cent of eyes with necrotizing disease associated with inflammation, and in 77 per cent of those without inflammation. The rest of these eyes developed severe thinning without sequestration. Of eyes with scleral defects 59 per cent also had keratitis, although this was accompanied by a loss of corneal tissue (keratolysis) in only three eyes (Fig. 16). No scleral defects developed in patients who had episcleritis or any of the less severe forms of scleritis.

\section{Associated systemic diseases}

The incidence of the various systemic conditions detected in this series is summarized in Table XI.

In eyes where scleritis and episcleritis coexisted, the area of severe damage occurred where the sclera was involved, and not where the episclera was inflamed without deep involvement.

We have observed, however, that the patients with herpes zoster ophthalmicus developed an episcleritis at the time of the vesicular eruption. The episcleritis disappeared as the skin condition subsided. Three patients developed a severe nodular scleritis two or three months later at the site of the original lesion. This does not imply that the episcleritis progressed to the scleritis, because there was a distinct interval between the two episodes during which the eye was apparently normal. Since making this observation we have studied a further 20 patients who were not included in this series presenting with herpes zoster ophthal- 
Table XI Incidence of associated systemic diseases in episcleritis and scleritis

\begin{tabular}{|c|c|c|c|c|c|c|c|}
\hline \multirow[b]{2}{*}{ Disease } & \multicolumn{2}{|c|}{ Episcleritis } & \multicolumn{5}{|l|}{ Scleritis } \\
\hline & Simple & Nodular & $\begin{array}{l}\text { Diffuse } \\
\text { anterior }\end{array}$ & $\begin{array}{l}\text { Nodular } \\
\text { anterior }\end{array}$ & $\begin{array}{l}\text { Necrotizing } \\
\text { anterior }\end{array}$ & $\begin{array}{l}\text { Scleromalacia } \\
\text { perforans }\end{array}$ & Posterior \\
\hline Rheumatoid arthritis & 5 & 2 & 8 & 4 & 3 & 6 & - \\
\hline Ankylosing spondylitis & $\circ$ & 0 & $\mathbf{I}$ & 0 & 0 & ○ & ○ \\
\hline $\begin{array}{l}\text { Psoriatic arthritis } \\
\text { Systemic lupus }\end{array}$ & $\circ$ & $\circ$ & $\circ$ & 3 & ○ & $\circ$ & $\circ$ \\
\hline erythematosus & ○ & 0 & 0 & I & $\mathbf{I}$ & 0 & ○ \\
\hline Periarteritis nodosa & $\circ$ & ○ & ○ & ○ & 2 & ○ & o \\
\hline Systemic vasculitis & $\circ$ & $\circ$ & $\mathbf{I}$ & ○ & I & $\circ$ & o \\
\hline Wegener's granulomatosis & ○ & $\circ$ & o & 0 & $\mathbf{I}$ & $\circ$ & $\circ$ \\
\hline Relapsing polychondritis & $\circ$ & $\circ$ & o & o & 2 & $\circ$ & $\circ$ \\
\hline Rheumatic heart disease & 2 & $\mathbf{I}$ & $\mathbf{I}$ & $\mathbf{I}$ & ○ & ○ & ○ \\
\hline Palindromic rheumatoid & ० & $\circ$ & $\circ$ & ० & 2 & ○ & o \\
\hline \multicolumn{8}{|l|}{$\begin{array}{l}\text { Associated with hypersensitivity } \\
\text { disorders }\end{array}$} \\
\hline Erythema nodosum & 0 & o & ० & 2 & ○ & ० & ○ \\
\hline Severe asthma or hay fever & ○ & ○ & 2 & $\circ$ & ○ & ○ & $\circ$ \\
\hline Erythema multiforme & $\mathbf{I}$ & o & $\circ$ & 0 & 0 & 0 & o \\
\hline Henoch-Schönlein purpura & $\mathbf{I}$ & 0 & $\circ$ & $\circ$ & ○ & o & $\circ$ \\
\hline Penicillin sensitivity & 2 & ० & o & ○ & 0 & ○ & $\circ$ \\
\hline Contact dermatitis & 2 & $\mathbf{I}$ & ○ & ○ & o & o & ○ \\
\hline After desensitization & & & & & & & \\
\hline vaccination & 2 & ○ & ○ & ○ & ○ & ○ & ○ \\
\hline Rosacea & $\mathbf{I}$ & 2 & 0 & 2 & $\circ$ & ० & $\circ$ \\
\hline \multicolumn{8}{|l|}{$\begin{array}{l}\text { Associated with granulomatous } \\
\text { conditions } \\
\text { Tuberculosis }\end{array}$} \\
\hline Active & $\mathbf{I}$ & $\circ$ & $\mathbf{I}$ & $\circ$ & 3 & ○ & o \\
\hline Inactive & $\mathbf{I}$ & 2 & ○ & ○ & 0 & ○ & ○ \\
\hline Syphilis & $\circ$ & $\mathbf{I}$ & $\mathbf{I}$ & 3 & 2 & ○ & ० \\
\hline \multicolumn{8}{|l|}{ Associated with virus infection } \\
\hline Herpes zoster & 2 & $\mathbf{I}$ & 2 & 14 & ○ & ○ & ○ \\
\hline Herpes simplex & $\circ$ & $\circ$ & ○ & 2 & ○ & ○ & ○ \\
\hline \multicolumn{8}{|l|}{$\begin{array}{l}\text { Associated with metabolic } \\
\text { disorders }\end{array}$} \\
\hline Gout & 6 & 5 & 2 & 3 & 0 & 0 & 0 \\
\hline Other associated conditions* & I & 0 & Io & 7 & I & 0 & 0 \\
\hline
\end{tabular}

*In simple episcleritis one patient had regional ileitis

In diffuse anterior scleritis Io patients had other diseases-orbital granuloma (I), essential hypertension (3), postirradiation to other eye (1), fragilitas osseum (I), thyrotoxicosis (I), degenerative osteoarthritis (2), ankylosing spondylitis (I)

In nodular anterior scleritis seven patients had other diseases-for example, Cogan's syndrome (3), thyrotoxicosis (2), ophthalmia nodosa (1), hypertension ( $\mathrm{I}$ )

One patient with necrotizing scleritis had hypertension as the only other systemic disease. There was no other evidence of a generalized systemic vasculitis

micus and episcleral disease. This phenomenon of late appearance of scleral disease was observed in seven of the 20 patients ( 35 per cent).

\section{Laboratory investigations}

The various laboratory investigations carried out in these patients are mentioned on page 165 .
In the latter part of the series plasma protein estimations and electrophoresis were performed routinely in all patients with scleritis, and an immunological survey performed by the Immunology Department of the University of Glasgow. Although these results apply only to those patients who were seen during the last nine months of the analysis, they are shown in Table XIII because they showed 
Table XII Laboratory investigations : abnormal findings in patients

\begin{tabular}{|c|c|c|c|c|}
\hline \multirow{2}{*}{ Test } & \multicolumn{2}{|c|}{ Episcleritis } & \multicolumn{2}{|c|}{ Scleritis } \\
\hline & No. & (per cent) & No. & (per cent) \\
\hline $\begin{array}{l}\text { Erythrocyte sedimen- } \\
\text { tation rate }\end{array}$ & 22 & 14 & 76 & 37 \\
\hline $\begin{array}{l}\text { White blood count } \\
\text { Latex test for }\end{array}$ & 7 & 4 & 14 & 7 \\
\hline rheumatoid factor & 12 & 7 & 28 & 13.5 \\
\hline Wassermann reaction & $\mathbf{I}$ & 0.6 & 6 & 3 \\
\hline Uric acid & 18 & II 3 & 14 & 7 \\
\hline
\end{tabular}

that a more sophisticated survey would reveal evidence of immunological abnormality not revealed by routine laboratory testing.

Of the 48 patients with scleritis, 27 ( 56 per cent) had some positive result in the immunological test. Eight patients had more than one positive result. These are presented with a control series of 30 patients matched for age and sex, with eye disease but with no scleral or uveal involvement.

Of the 12 patients with a positive result in the rheumatoid arthritis latex agglutination test, only two had clinical rheumatoid arthritis.

\section{Skin tests}

Intradermal or prick tests-inhalant, mould, fabric, dusts, and pollens - were performed in 30 patients with episcleritis, particularly those who gave some history of allergy. Mild reactions were detected to several agents in eight patients, but no overall pattern of allergic response as judged by this response could be detected. Two patients gave a history of a flare-up of episcleritis when in contact with printer's ink. The results of intradermal, patch and prick tests were negative, but vapour exposure produced flushing of the episclera.

\section{$\boldsymbol{X}$-ray examination}

$X$-ray examination of the chest and sacro-iliac joints was carried out routinely in all patients with scleritis unless there was some contraindication. The seven-day rule with regard to ovulation was applied. Other examinations were carried out if indicated. Of patients in this series 42 per cent were intensively investigated by Fowler (1970), who found sacro-iliac abnormalities in seven, of whom three had definite ankylosing spondylitis. Only one patient had symptoms which would have led to this diagnosis without specific examination.

\section{Electrodiagnostic investigations}

Electro-oculograms (EOG) were performed initially in all patients; later in the series they were performed if the patient had severe disease or posterior scleritis. In 7 I consecutive patients with episcleritis and scleritis presenting in the scleritis clinic, 13 had subnormal EOGs in the affected eye. All but one of these patients had scleritis but this was not severe in every case. The other patients had recurrent episcleritis and glaucoma.

\section{Tissue biopsy}

Biopsy of scleral tissue is not recommended unless there is great difficulty in diagnosing the eye condition or the underlying systemic disease. Episcleral biopsies were performed on three patients to try to elucidate the underlying disease. Two showed infiltration of the tissue with chronic inflammatory cells including occasional plasma cells, but no changes specific to any other disease. One revealed a lymphomatous infiltration of the episclera.

\section{Treatment (see pages 187 to 189 )}

The various medical treatments given for scleritis and episcleritis are summarized in Tables XIV and XV. Recently oxyphenbutazone (Tanderil) ophthalmic ointment has been used in episcleritis and has been the subject of a double-blind controlled trial (Watson, McKay, Clemmett, and Wilkinson, 兰 I973), but it was not used in the patients in this series.

\section{Surgical treatment}

Three cataracts have required extraction in the

Table XIII Tissue antibody responses

\begin{tabular}{|c|c|c|c|c|c|c|c|c|}
\hline Patients & $\begin{array}{l}\text { Antinuclear } \\
\text { factor }\end{array}$ & $\begin{array}{l}\text { Rheumatoid } \\
\text { factor } \\
\text { (latex) }\end{array}$ & $R_{3}$ & $\begin{array}{l}\text { Thyroid } \\
\text { antibody }\end{array}$ & $\begin{array}{l}\text { Tanned } \\
\text { RBC }\end{array}$ & $\begin{array}{l}\text { Smooth } \\
\text { muscle }\end{array}$ & $\begin{array}{l}\text { Gastric } \\
\text { parietal }\end{array}$ & $\begin{array}{l}\text { Raised } \\
\gamma \text {-globulin }\end{array}$ \\
\hline $\begin{array}{l}\text { Scleritis (48) } \\
\text { Control }(30)\end{array}$ & 3 & 12 & 2 & 5 & 2 & 7 & 6 & 4 \\
\hline Control (30) & $\circ$ & $\circ$ & 0 & 2 & $\circ$ & $\mathbf{I}$ & 2 & 0 \\
\hline
\end{tabular}


presence of active scleritis. No complications followed these operations.

Four patients have had corneo-scleral grafts for descemetocele formation, expansion of the globe, increasing corneal guttering, and threatened perforation (Fig. 19). All have done well.

Two patients were given scleral grafts to cover thin sclera. The graft remained in place in one; in the other patient the graft became involved by scleritis and eroded away, leaving the choroid covered by a thin layer of conjunctiva. The course of the scleral disease was not influenced by the grafting.

Table XIV Treatments given in episcleritis

\begin{tabular}{|c|c|c|}
\hline Treatment & $\begin{array}{l}\text { Simple } \\
\text { episcleritis }\end{array}$ & $\begin{array}{l}\text { Nodular } \\
\text { episcleritis }\end{array}$ \\
\hline Not known & 2 & 3 \\
\hline Placebo & 6 & $\circ$ \\
\hline Local prednisolone drops & 80 & 17 \\
\hline Systemic prednisolone & 2 & $\mathbf{I}$ \\
\hline Systemic sintisone & 3 & 2 \\
\hline Systemic other steroid & 0 & 0 \\
\hline Systemic antibiotics & ○ & ○ \\
\hline Systemic oxyphenbutazone & 22 & 2 \\
\hline Systemic indomethacin & 2 & 2 \\
\hline Other systemic treatment & & \\
\hline $\begin{array}{l}\text { for example, aspirin } \\
\text { Local steroid with }\end{array}$ & 4 & $\mathbf{I}$ \\
\hline $\begin{array}{l}\text { systemic steroid } \\
\text { Local steroid with systemic }\end{array}$ & Io & 4 \\
\hline $\begin{array}{l}\text { oxyphenbutazone } \\
\text { Local steroid with systemic }\end{array}$ & 17 & 9 \\
\hline indomethacin & 5 & 0 \\
\hline Other antibiotics & 17 & 6 \\
\hline
\end{tabular}

\section{Enucleation}

Scleritis is a serious condition and even if fully and carefully treated can lead to the loss of the eye, as indeed happened in three of the patients in this series. Only one of these patients was seen early in the disease and she was not able to tolerate steroid treatment; the eye was removed for intractable pain after the necrotizing disease had spread inexorably around the globe. The vision was preserved until the last area of undamaged sclera became involved, but then fell rapidly from $6 / 18$ to hand movements within a week. Another eye was removed because it was blind and extremely painful. The third patient had severe keratolysis and necrotizing scleritis with loss of corneal and scleral tissue when first seen. Attempts at covering these defects by grafting failed and the eye was eventually removed.

\section{Follow-up}

Of the 159 patients with episcleritis and the 207 patients with scleritis, I46 (9I per cent) and I 86 (90 per cent), respectively, have been followed-up during a period of between one and eight years (mean 5.8 years). All the patients who had not attended the clinic for six months and had had the disease for at least one year were sent a questionnaire in an attempt to determine the recurrence rate. Altogether 332 patients, of 366 who were circularized (9I per cent), replied to the questionnaire or returned to the clinic for follow-up.

In cases in which scleritis was seen in the initial stages and fully treated the recurrence rate was only 20 per cent. The recurrence rate was higher in those patients with anterior diffuse scleritis than

Table XV Treatments given in scleritis

\begin{tabular}{|c|c|c|c|c|c|}
\hline \multirow{2}{*}{ Treatment } & \multicolumn{4}{|l|}{ Anterior } & \multirow{2}{*}{ Posterior } \\
\hline & Diffuse & Nodular & Necrotizing & $\begin{array}{l}\text { Scleromalacia } \\
\text { perforans }\end{array}$ & \\
\hline Not known & 2 & 7 & ○ & $\circ$ & $\circ$ \\
\hline Placebo & $\circ$ & 0 & $\circ$ & 0 & $\circ$ \\
\hline Local steroid & 22 & 34 & $\circ$ & $\mathbf{I}$ & 0 \\
\hline Systemic prednisolone & 10 & $\begin{array}{r}34 \\
7\end{array}$ & $\mathbf{I}$ & 2 & $\circ$ \\
\hline Systemic sintisone & 7 & 12 & 0 & 0 & 0 \\
\hline Systemic antibiotics & 0 & $\mathbf{I}$ & 0 & 0 & $\circ$ \\
\hline Systemic oxyphenbutazone & 7 & 5 & 2 & 2 & $\circ$ \\
\hline Systemic indomethacin & 4 & I & 0 & 0 & $\mathbf{I}$ \\
\hline Other systemic treatment & I & I & 0 & $\circ$ & 0 \\
\hline Local steroid with systemic steroid & 19 & 14 & 7 & 5 & 2 \\
\hline Other systemic steroid & 0 & 0 & 0 & 0 & 0 \\
\hline Local steroid with systemic oxyphenbutazone & 17 & $2 \mathbf{I}$ & 5 & $\circ$ & 2 \\
\hline Local steroid with systemic indomethacin & 4 & 4 & 0 & $\circ$ & $\circ$ \\
\hline Other combinations & 26 & 27 & 14 & 3 & $\mathbf{I}$ \\
\hline
\end{tabular}




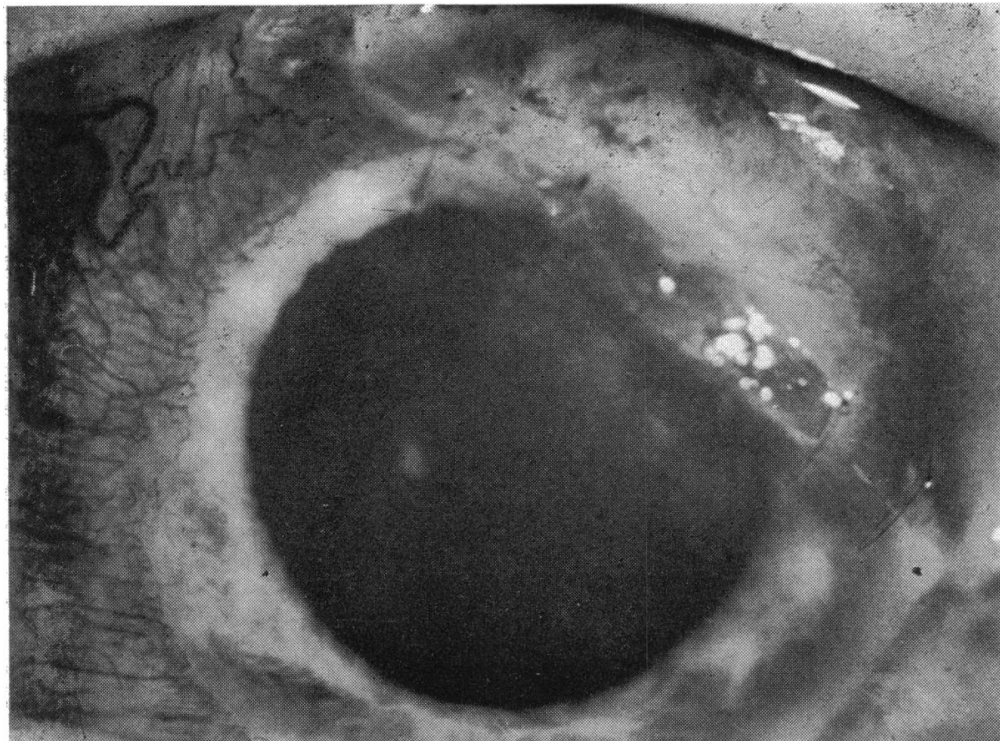

FIG. 19 Overlay corneo-scleral lamellar graft on same patient as in Fig. I 5 whose astigmatism was reduced from ${ }_{5} D$ to $6 D$ by this procedure. Grafting only adds supporting tissue and does not affect underlying pathology

with any other variety. The recurrences were also more severe in scleritis than episcleritis, 60 per cent of them requiring further hospital treatment.

It is important to follow up those patients with necrotizing disease because the disease can continue to progress when they are symptom-free, and they may require continuous treatment even when the disease is quiescent.

In episcleritis, however, each attack is selflimiting and usually clears without treatment. This has been confirmed in a double-blind controlled trial (Watson and others, 1973) in which each attack varied from a few hours to several days, the average being about seven days. Episcleritis was most common in the interpalpebral region, often changing from one side to the other with each attack. However, some patients always developed the inflammation at the same site although recurrences of both episcleritis and scleritis could occur up to 30 years after the onset of the disease (Table XVII).

Two-thirds of the patients had recurrences up to six years after the onset of the disease, but after this the recurrence rate fell. We found that there was often a considerable interval between the onset of the disease and the first attendance of the patient, who often came only because of apprehension caused by the recurrent attacks rather than the severity of the symptoms.

\section{Deaths (Table XIX)}

Of the 14 patients who were known to have died during the period of follow-up, only two had episcleritis. One died as a result of a road accident, and the other committed suicide. Of the remaining patients, six (43 per cent) had had necrotizing scleral disease, one diffuse anterior scleritis, and five nodular scleritis. None of the patients with scleromalacia perforans was known to have died during this period, although many of these patients

Table XVI Duration of disease

\begin{tabular}{|c|c|c|c|c|c|c|c|c|}
\hline \multirow{2}{*}{ Disease } & \multicolumn{2}{|c|}{ Months } & \multicolumn{6}{|c|}{ Years } \\
\hline & 6 & 18 & 3 & 6 & 10 & 15 & 20 & 30 \\
\hline Episcleritis & $\overline{6}$ & $\overline{35}$ & $\overline{24}$ & $\overline{17}$ & $\overline{\text { II }}$ & $\overline{29}$ & - & - \\
\hline Scleritis & 10 & 34 & 24 & 19 & 6 & I & 0 & 6 \\
\hline
\end{tabular}

Table XVII Percentage of recurrences

\begin{tabular}{|c|c|c|c|c|c|}
\hline \multirow[b]{2}{*}{ Recurrence } & \multirow[b]{2}{*}{ Total } & \multirow[b]{2}{*}{$\begin{array}{l}\text { Same } \\
\text { eye }\end{array}$} & \multirow[b]{2}{*}{$\begin{array}{l}\text { Other } \\
\text { eye }\end{array}$} & \multicolumn{2}{|l|}{ Both eyes } \\
\hline & & & & $\begin{array}{l}\text { Simul- } \\
\text { taneously }\end{array}$ & $\begin{array}{l}\text { At different } \\
\text { times }\end{array}$ \\
\hline Episcleritis & 64 & 46 & 5 & 27 & 22 \\
\hline Scleritis & 69 & 48 & 4 & 31 & 15 \\
\hline
\end{tabular}

Table XVIII Severity of recurrences (per cent)

\begin{tabular}{llllll}
\hline & & \multicolumn{3}{c}{ Treatment needed } \\
\cline { 5 - 6 } Disease & $\begin{array}{l}\text { Not } \\
\text { severe }\end{array}$ & $\begin{array}{llll}\text { At } \\
\text { hospital }\end{array}$ & $\begin{array}{l}\text { By own } \\
\text { doctor }\end{array}$ & $\begin{array}{l}\text { By self- } \\
\text { medication }\end{array}$ \\
\cline { 5 - 6 } & Episcleritis & $3 \mathrm{I}$ & 38 & 26 & 4 \\
Scleritis & 27 & 60 & 13 & 1 \\
\hline
\end{tabular}


Table XIX Cause of death in the I4 patients who died during the period of follow-up

\begin{tabular}{|c|c|c|c|c|}
\hline Patient & Sex & Type of scleritis & General conditions & Cause of death \\
\hline $\mathbf{I}$ & Female & Necrotizing & $\begin{array}{l}\text { Rheumatoid arthritis } \\
\text { Cardiovascular disease }\end{array}$ & Coronary thrombosis \\
\hline 2 & Female & Necrotizing & Rheumatoid arthritis & Bronchopneumonia \\
\hline 3 & Male & Necrotizing & $\begin{array}{l}\text { Diffuse connective-tissue disease } \\
\text { Chronic nephritis } \\
\text { Hypertension }\end{array}$ & Cerebral haemorrhage \\
\hline 4 & Female & Necrotizing & Hypertension & Cerebral haemorrhage \\
\hline 5 & Female & Necrotizing & $\begin{array}{l}\text { Bronchitis } \\
\text { Emphysema }\end{array}$ & Congestive heart failure \\
\hline 6 & Male & Necrotizing & $\begin{array}{l}\text { Pulmonary tuberculosis } \\
\text { Emphysema } \\
\text { Bronchiectasis }\end{array}$ & Bronchopneumonia \\
\hline 7 & Male & Diffuse anterior & Polyarteritis nodosa & Gastrointestinal haemorrhage \\
\hline 8 & Male & Nodular & Rheumatoid arthritis & Coronary thrombosis \\
\hline 9 & Male & Nodular & & Myocardial infarction \\
\hline 10 & Male & Nodular & Old herpes zoster ophthalmicus & Myocardial infarction \\
\hline I I & Male & Nodular & Old herpes zoster ophthalmicus & Myocardial infarction \\
\hline 12 & Male & Nodular & & Stabbed to death \\
\hline 13 & Male & Nodular & & Suicide \\
\hline 14 & Male & Simple episcleritis & & Road accident \\
\hline
\end{tabular}

had long-standing rheumatoid arthritis and were generally unwell at the time of their initial examination. Unfortunately three of these patients were not found for follow-up and might well have died in the interim. Of those who died of natural causes, 54 per cent had necrotizing disease, and 27 per cent of the patients with severe necrotizing scleritis were dead within eight years of the onset of the scleritis.

Five of the patients who died were known to have had diffuse connective-tissue disease; 2 I per cent of all those with connective-tissue disease in this series. Another had hypertension and, it was thought, could have had a systemic vasculitis. As no necropsy was performed this could not be confirmed.

\section{Discussion}

While scleritis is an uncommon disease, accounting for only 0.08 per cent of new referrals to eye departments (Williamson, 1974), of those with the necrotizing disease $2 \mathrm{I}$ per cent died within eight years of the onset. The presence of scleritis may therefore portend serious systemic disease. Early diagnosis may lead to early treatment of the general condition, prolonging and probably improving the quality of life for these patients.

In our present series 46 per cent of the patients with scleritis had a known associated systemic condition. Of these, I5 per cent had definite connective-tissue disease, confirmed by a rheumatologist (Table XI). This incidence has recently been confirmed in an analysis of a further 88 patients with scleritis, in whom the incidence of associated systemic disease was 42 per cent, of which 15 per cent consisted of connective-tissue diseases.

It has been suggested in the literature (DukeElder and Leigh, 1965) that rheumatoid arthritis is the commonest single associated condition, but it was found in only io per cent of our patients. Scleritis also occurs in association with other connective-tissue diseases-systemic lupus erythematosus, polyarteritis nodosa, relapsing polychondritis, Wegener's granulomatosis - thus reflecting the collagenous nature of the tissue of which the sclera is composed. Altogether 31 patients (I 5 per cent) were found to have manifest connective-tissue disease; in seven of these the scleritis was the presenting feature. In 19 other patients there were conditions thought to have been immunologically induced, including two who had erythema nodosum. A total of 40 had positive latex agglutination tests for rheumatoid arthritis and a positive antinuclear factor, and if all the immunological tests are included, 72 patients ( 35 per cent) in the series tested had some abnormality of this type.

It seems that necrotizing scleral disease represents a different phase of scleritis in certain patients. In some patients who have had recurrent scleral disease for many years the scleritis has changed in type, coinciding with a change in the character of the systemic disease-for example, the onset of vasculitis in rheumatoid arthritis and renal disease in systemic lupus erythematosus. In other patients the onset of disease is 'malignant' wit progressive and inexorable destruction of scleri.. tissues if treatment is not adequate. The mortality 
in this group is very high. Finally, there appears to be yet another type of scleral disease, scleromalacia perforans, which is almost completely confined to women, half of whom have long-standing rheumatoid arthritis. In these sequestration of the sclera occurs without warning and little, if any, inflammation. This type of scleral reaction is neither the same as that found in other forms of scleritis nor does it necessarily have the same pathogenesis.

A biopsy is contraindicated in scleral disease because the sclera does not heal easily - a fact well known to surgeons performing detachment operations a few years ago when scleral surgery was the rule. Large scleral nodules often contain pultaceous material which, if released, exposes the underlying choroid, but they may heal with fibrosis if left alone (Watson, 1974). Much of our knowledge of the underlying processes has therefore to be derived from the few biopsy specimens which have become available, and from those eyes which have been enucleated for severe disease (Sevel, 1967; Verhoeff and King, 1958; Anderson and Margolis, 1952; François, 1970; Henkind, 1974). This unfortunately means that we can find out little about the disease in most of the patients other than what can be deduced from their clinical examination and serological investigations. Biopsy of the episcleral lesions showed oedema, separation of the episcleral fibres, infiltration with lymphocytes, and some cuffing of the vessels. Henkind and Gold (1973) observed a rheumatoid nodule in the episcleral tissue but we have not seen this. It is certain, however, that the changes typical of rheumatoid nodules occur in the sclera in certain patients with necrotizing scleritis and rheumatoid arthritis. More typical, however, is a granulomatous reaction in the sclera, similar to that found elsewhere in the body in connective-tissue disease, the predominant feature being fibrinoid necrosis. Similar lesions can be produced in animals with the Schwartzmann reaction. It was probable therefore that in many cases the altered immunity in the patient was the underlying cause of this condition. The sclera is also involved in gout, in which the response is due to inflammation caused by proteolytic enzymes released from polymorphs which have ingested uric acid crystals.

The chronic granulomatous diseases of bacterial origin have also been quoted as a cause of scleritis (Duke-Elder and Leigh, 1965). We saw only two patients with active pulmonary tuberculosis and scleritis, although ancient photographs and histological sections make it clear that this was a much commoner condition when tuberculosis was severe and less easily treatable. We have not knowingly seen scleritis in association with sarcoidosis.

Syphilis, however, can present as a scleritis. Four patients have presented in this way with the eye changes as their only symptom. They were found to have severe active syphilis with a positive cerebrospinal fluid serological result. The scleritis disappeared when the syphilis was fully treated. Altogether I4 patients had a positive Wassermann reaction in this series, seven presented with simple episcleritis and the others with a diffuse anterio and nodular scleritis. The scleritis associated with syphilis and tuberculosis was in no way different from the other forms.

The aetiology of episcleritis is even more uncertain. However, two patterns are apparent. Most patients have intermittent bouts of moderate or severe inflammation at intervals of one to three months, lasting seven to ten days and occurring much more commonly during the spring and autumn than in the summer or winter. Only rarely can any certain precipitating factor be found, the attacks usually being related to family upsets and worries at work. Occasionally, however, a clear history of exogenous sensitization is given-for example, contact with printer's inks. In one instance the patient had only to be inside the printing works for his eyes to flare up; exposure to the vapours of the ink also produced an attack under hospital conditions, but skin tests gave negative results. I I per cent of patients with episcleritis had recurrently high serum uric acid values (more than $6.5 \mathrm{mg}$ per cent on three readings), and 7 per cent had clinical gout. I 2 per cent also had a history of asthma and hay fever; only one patient related the attacks to menstruation. Two patients developed episcleritis after a desensitization vaccination.

The second group of patients gave no history of periodicity but rather of mild, prolonged attacks of inflammation. Into this category came almost all those patients who had some other intercurrent disease. Seven patients had a positive Wassermann reaction (one with active syphilis), four had mild rheumatoid arthritis with a positive rheumatoid factor but only a few joint symptoms, and two had erythema multiforme; the others had active tuberculosis, Henoch-Schönlein purpura, or rosacea. Herpes simplex virus has been grown from one lesion. The appearances of the episcleritis did not differ in these two groups, and in neither did the episcleritis progress to a scleritis except in those patients with herpes zoster who have already been discussed. General physical examination and chest $x$-ray failed to reveal any evidence of focal sepsis.

Herpes zoster involves both the cornea and sclera. As already discussed, an episcleritis may occur in the early vesicular stage of the disease, disappearing completely and then presenting as a deep localized scleritis at the site of the original lesion some two to three months later. Alternatively the sclera may be involved early in the disease, in which case a nodular scleritis is the rule. 
Clinical gout was found in five patients who presented with episcleral and scleral disease, and 32 had raised levels of uric acid on more than one occasion. The serum uric acid is a notoriously unreliable test and a single positive recording should not be taken as indicative of underlying gout. It was observed that those patients with clinical gout and scleral and episcleral disease had deposits of uric acid beneath the conjunctiva around the anterior ciliary vessels at the plica. It was hoped that this could be used as a diagnostic sign, but deposits which look almost identical are frequently seen in patients whose serum uric acid is normal.

It could be suggested that this group of patients with episcleritis may represent the earlier stages of a benign form of scleritis. If this was so, one would expect a significant number of cases to progress from episcleritis to scleritis, but during the eightyear period of follow-up we did not see this. We did see three patients who had episcleritis in one part and scleritis in another part of the same eye. However, it is an interesting and definite observation that the episcleritis did not progress to scleritis even during a prolonged follow-up. We feel that this suggests that episcleritis and scleritis are two different types of reaction to a similar antigen within the different tissues. Thus the fact that the episclera is involved in the course of the disease does not mean that the underlying sclera would become involved, even after a long period of time. We have, as yet, no definite evidence that scleritis is an autoimmune disease, and the evidence presented in this paper is only circumstantial. Equivalents of Koch's postulates which need to be satisfied for auto-immune disease are as follows (Glynn, 1974):

I. There must be a specific antigen. It may not be from the tissue involved in order that complexes may be formed elsewhere. In general, one would expect the antigen to be found at the site of the lesion, for instance the thyroid antigen in autoimmune thyroiditis. It should be possible to:

2. Extract the antigen.

3. Reproduce the disease in some experimental animal.

4. Demonstrate specific antibodies to the antigen or specifically sensitize cells reacting with antigen.

We were not able to fulfil these postulates partly because of the undesirability of obtaining biopsy tissue in our patients, and because of uncertainty that the disease produced in animals was of the same nature. However, the circumstantial evidence from the well-proven association with known connectivetissue disease is strongly suggestive that this is a manifestation of immune complex disease in a large number of cases. In herpes zoster ophthalmicus and gout the precipitating cause is known, but until more is known about the precipitating factors of the immune-complex disease we are not justified in making any further conclusions.

Whatever the pathogenesis might be, we found that by careful differential diagnosis we were able to treat the disease appropriately and adequately so as to prevent a serious destructive change taking place in the eye. The differential diagnosis of scleritis and episcleritis is summarized in Table XX.

\section{TREATMENT}

Apart from the very few patients in whom a specific bacterial or viral agent could be found to

Table XX Cardinal features in the differentiation of scleritis from episcleritis

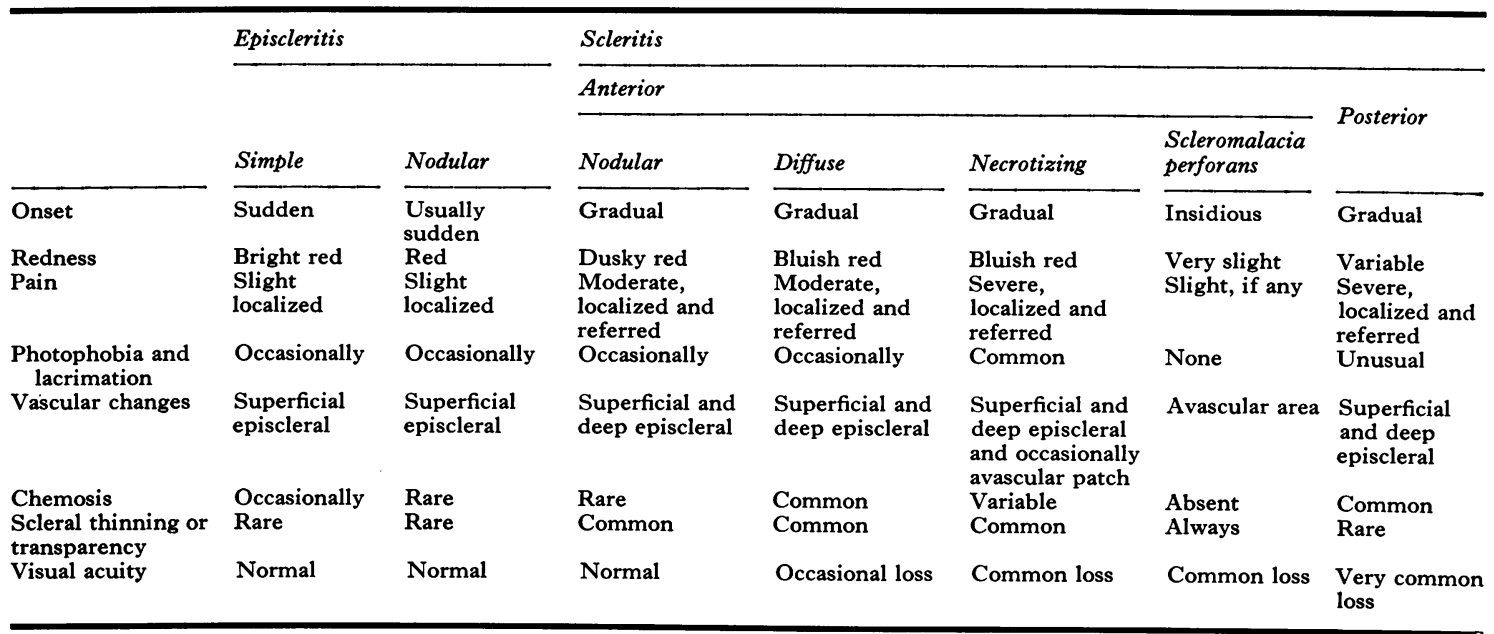


have caused episcleritis or scleritis, the treatment is suppression of the inflammation in order to relieve the discomfort and prevent the destructive changes which may accompany the inflammation. Treatment, which must be continued until the disease has followed its natural course, has proved to be effective and many eyes are being saved or prevented from developing severe complications. Only three eyes ( 0.6 per cent) were lost-one that of a patient who could not tolerate the treatment rather than because of the severity of the eye disease.

\section{EPISCLERITIS}

As the condition is self-limiting, harmless, and frequently symptomless, treatment may not be necessary. Double-blind controlled studies have been conducted to determine first whether any treatment was necessary and secondly which drugs were most effective in suppressing the inflammation.

In this trial some patients received placebo, others local steroid ointment, and the remainder oxyphenbutazone ointment. All the patients recovered within Io days. Both oxyphenbutazone eye ointment and betamethasone ointment appeared to hasten the recovery by about one day, but the differences were not significant (Watson and others, 1973) (Fig. 20).

If it is felt necessary to treat the patient, either because of the symptomatology or because of

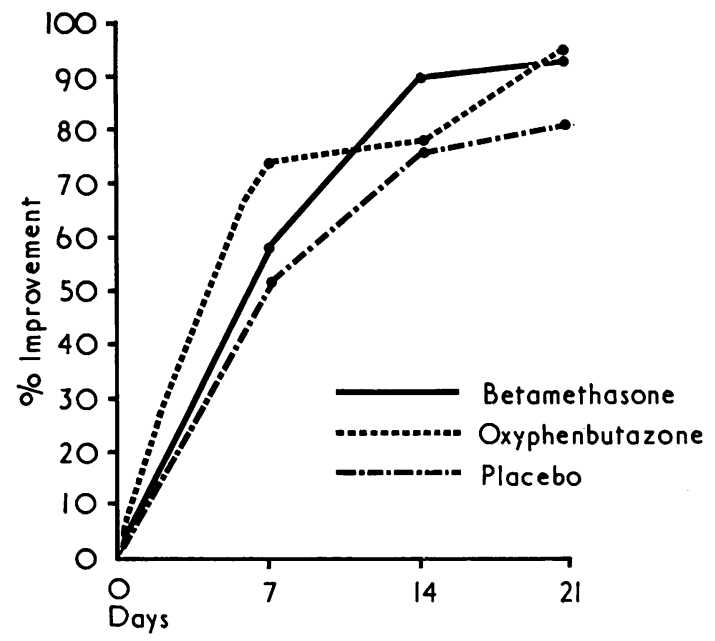

FIG. 20 Improvement of conjunctival and episcleral injection in patients with episcleritis treated with either placebo, oxyphenbutazone ointment or betamethasone I per cent ointment. Although those treated with active substances improved slightly faster, 80 per cent of those receiving placebo had recovered by $2 \mathrm{I}$ days multiple recurrences, we recommend the following routine:

Topical medication: Any one of the following medications may be used:

I. Prednisolone eye drops 0.5 per cent hourly until 24 hours after the inflammation has subsided, then reduced to three times a day for a further four days.

2. Betamethasone (Betnesol) eye ointment I per cent four times a day during the attack, and for a further week after the attack has subsided.

3. Oxyphenbutazone (Tanderil) eye ointment ro per cent four times a day during the attack, and for a further week after the attack has subsided.

Systemic therapy : Occasionally patients will not respond adequately to local therapy, in which case systemic oxyphenbutazone, indomethacin (Indocid), or corticosteroid may be needed.

I. Oxyphenbutazone: $600 \mathrm{mg}$ daily in divided doses is given until there is a response. The dose is then reduced to $400 \mathrm{mg}$ until the eye is quiet and then it is stopped. This treatment is given in addition to local treatment.

2. Indomethacin: If the patient fails to make a rapid recovery the drug may be changed to indomethacin $100 \mathrm{mg}$ daily in divided doses, and then reduced to $75 \mathrm{mg}$ as soon as there is a response. A double-blind controlled study just completed indicates that oxyphenbutazone and indomethacin are equally effective as anti-inflammatory agents, although some patients respond better to one drug than the other.

3. Corticosteroids: In the rare case which does not respond to local treatment, or systemic oxyphenbutazone or indomethacin, it is justifiable to give a short, intensive course of prednisolone or its equivalent. A suppressive dose for this condition is $60 \mathrm{mg}$ prednisolone daily which, as soon as the inflammation starts to regress, can be reduced rapidly with a view to withdrawing the drug entirely within one month.

A double-blind controlled study was carried out in these patients (Watson, Lobascher, Sabiston, Lewis-Faning, Fowler, and Jones, 1966) which revealed that both oxyphenbutazone and prednisolone were effective, but that patients receiving systemic prednisolone had a rebound of their symptoms, while those having oxyphenbutazone remained symptom-free.

\section{SCLERITIS}

Because of the depth and severity of the inflammation local steroid treatment is ineffective. Drops 
or ointment are soothing and reduce the inflammation but are not sufficient to control the scleritis.

As a result of our experience we have come to the conclusion that the following regimen of treatment is the most likely to be effective:

As soon as scleritis is diagnosed:

Systemic oxyphenbutazone $600 \mathrm{mg}$ daily in divided doses for four days, followed by $400 \mathrm{mg}$ daily until the condition is suppressed. This dosage is continued for one week after all symptoms have subsided. Or

Systemic indomethacin $100 \mathrm{mg}$ daily in divided doses, reduced to $75 \mathrm{mg}$ daily in divided doses as soon as there is a response. Treatment is continued until the condition has been quiescent for seven days.

These two drugs appear to be more effective than any of the other anti-inflammatory agents in general use-for example aspirin, ibuprofen (Brufen), etc.

\section{Local steroids}

Usually prednisolone or betamethasone can be given in addition.

\section{Subconjunctival steroids are not recommended in scleritis}

We have seen two patients in whom extreme thinning has occurred at the site of a subconjunctival injection of steroid (Watson, 1974; Fraunfelder and Watson, 1976). It is not certain whether it is the vehicle in which the steroid is contained or the steroid itself which is the irritating factor. We have from time to time given intraorbital steroid injections in patients unable to take steroid systemically. The effect is transient and the injections have to be repeated weekly to be effective. Most patients will not tolerate this regimen and so it is not satisfactory for routine use.

\section{Systemic corticosteroids}

If the scleritis is very severe, and does not respond to the oxyphenbutazone or indomethacin within a week, or if any avascular areas appear in the episclera, systemic steroids must be given in heavy suppressive doses. The sclera is avascular and high concentrations are required to produce a therapeutic effect.

\section{Systemic prednisolone}

$80 \mathrm{mg}$ a day in divided doses is usually sufficient as an initial dose. If it is effective the response is dramatic; although there is little change in 24 hours or even 48 hours, the pain disappears. The eye signs may not improve for a further 48 hours, after which time they rapidly regress. As soon as the condition is brought under control the dosage can be dropped within a week to a maintenance level which is usually between 10 and $20 \mathrm{mg}$ prednisolone daily. Cautious reduction from this level usually enables the patient to be taken off the drug or to be maintained with another anti-inflammatory agent within three to four weeks. In patients who have been unable to tolerate, or have failed to respond to, prednisolone, occasionally a response can be obtained with Sintisone (prednisolone 2I-stearoylglycolate), eight tablets (each tablet containing $0.63 \mathrm{mg}$ ) daily in divided doses (Hayreh and Watson, 1970). Why this preparation is so effective is uncertain, but we have several patients who have to be maintained on it rather than on the conventional steroids.

\section{Surgery}

Surgery is very rarely necessary in scleral disease. Provided the condition is seen early and treated vigorously, scleral necrosis can be largely prevented. Corneal grafting has had to be performed in four patients because of threatened perforation, an expanding globe, for peripheral corneal guttering, and for descemetocele. The corneal grafts have taken well and in all cases the scleritis has become less severe after this was done.

Many reports appear in the literature of scleral grafting for scleromalacia perforans (Holthouse, I893; Ashton and Hobbs, 1952; Torchia, Dunn, Pease, 1968; Vancea, Vancea, Jalobceastii, Colev, and Calin, 1971; Sevel and Abramson, 1972; and others). This has been necessary in only two patients in this series-neither of whom could tolerate steroids. In both patients the graft took well. In one the whole necrotic area was removed and the residual area of scleral inflammation could be controlled with local steroids and oxyphenbutazone systemically. In the other the necrotizing process continued from the edge of the scleral overlap and the eye was eventually lost, no other medical treatment being tolerated.

We consider scleritis to be a medically treatable condition, and provided the dosages of the drugs are adequate to suppress the inflammatory change, the condition will be controlled. In this we disagree with Sevel and Abramson (1972) and Aronson and Elliott (1974). We feel our results justify our claim.

\section{Summary}

The data from 159 patients (2I7 eyes) with episscleritis and 207 patients (301 eyes) with scleritis have been investigated in detail and the results analysed with the help of a computer. Of these patients, 9I per cent were followed-up during a 
period of one to eight years. A new classification is presented which is as follows:

Episcleritis (217 eyes)

Simple episcleritis (I70 eyes)

Nodular episcleritis (47 eyes)

Scleritis (301 eyes)

Diffuse anterior scleritis (I 19 eyes)

Nodular anterior scleritis (1 34 eyes)

Necrotizing scleritis (42 eyes). Of these, 13 were regarded as scleromalacia perforans.

Posterior scleritis (6 eyes)

The diagnosis is based on an exact clinical examination which is fully described.

Episcleritis has been shown to be a benign recurring condition, a mild keratitis being the only occasional complication. Episcleritis does not progress to scleritis, except in the case of herpes zoster which sometimes starts as an episcleritis with the vesicular stage of the eruption, to reappear three months later as a scleritis in the same site.

No clear conclusions could be drawn as to the aetiology of episcleritis.

Scleritis is always accompanied by episcleral inflammation which must be ignored in making the diagnosis. Scleritis is a much more severe disease than episcleritis, leading to loss of visual acuity from corneal changes, uveitis, cataract, or retinal detachment if not treated. Necrotizing scleritis with inflammation is the severest form of the disease and $2 \mathrm{r}$ per cent of the patients with this condition died within the eight-year-period of follow-up.

Connective-tissue disease was the commonest associated general condition; the incidence of necrotizing scleritis was higher in this group and
2I per cent of these patients were among those that died. It is probable that necrotizing scleritis represents the eye changes of the malignant phase of systemic connective-tissue disease.

Treatment is unnecessary in episcleritis but in scleritis systemic treatment with anti-inflammatory agents or corticosteroids is obligatory. Using these routines of treatment only three patients $(0.6$ per cent) have lost an eye.

Apart from ourselves, the following have worked in the Scleritis Clinic during the past ro years: A. Atkinson, P. Awdry, P. E. Cleary, R. S. Clemett, P. Fowler, A. Freedman, B. Hazleman, P. Henderson, A. D. Holt-Wilson, D. Jones, S. Lachmann, D. Lloyd-Jones, D. Lobascher, A. J. Lyne, and D. A. R. Mackay, and we would like to thank them all for their help and ideas. We are sure many of these ideas are incorporated in this article but it is impossible to acknowledge them properly because we have forgotten where they originated. We should also like to thank all those surgeons who have referred patients to us: without them there would be no clinic.

The computer analysis was completed at the Institute of Ophthalmology and many of the illustrations were reproduced there; the rest were done in the Medical Illustration Department of Addenbrooke's Hospital, Cambridge.

Figs 6 and 14 were reproduced from the Transactions of the Ophthalmological Society of the United Kingdom; Fig. 16 from Connective-tissue disease in the eye, in Recent Advances in Ophthalmology, ed. P. Trevor-Roper, published by Blackwell; and Fig. 20 from the British fournal of Ophthalmology.

Last but not least we should like to thank all those who have at various times typed part or all of this manuscript, in particular Mrs J. Field and Mrs J. McCombie.

\section{References}

ANDerson, B., and Margolis, G. (1952) Amer. F. Ophthal., 35, 917

ARONSON, S. B., and ElliotT, J. H. (1974) Scleritis, in 'Ocular Inflammatory Disease', ed. Bruce Golden, p. 43.

Thomas, Springfield, Ill.

ASHTON, N., and HOBBS, H. E. (1952) Brit. F. Ophthal., 36, 373

Clavel and teulières, J. (1958) Bull. Soc. Ophtal. Fr., II, 749

DESMARRES, L. A. (1847) 'Maladies des yeux', p. 360. Baillière, Paris

DUKE-ELDER, S., and LEIGH, A. G. (1965) In 'System of Ophthalmology', vol. VIII, chap. VIII. Kimpton, London

FOWLER, P. D. (1970) Ann. rheum. Dis., 29, 195

FRANCESChetTi, A., and BISChler, v. (1950) Ann. Oculist. (Paris), 183, 737

FRANÇOIS, J. (1970) Adv. Ophthal., 23, I

FRAUNFELDER, F. T., and WATSON, P. G. (1976) Brit. F. Ophthal., 6o, 227

FUCHS, E. (1895) v. Graefes Arch. Ophthal., 41, 229

GLYNN, L. E. (1974) Trans. ophthal. Soc. UK, 94, 783

GRAVES, B. (I937) Brit. F. Ophthal., 21, 534

HAYREH, s. S., and BAINES, J. A. B. (1972) Ibid., 56, 7 I 9

-

HENKIND, P. (1974) Trans. ophthal. Soc. UK, 94, 782

- and GOLD, D. H. (1973) Rheumatology, 4, I3

HOLTHOUSE, E. H. (1893) Roy. Lond. ophthal. Hosp. Rep., 13, 41

HOLT-Wilson, A. D., and Watson, P. G. (1974) Trans. ophthal. Soc. UK, 94, 52

mackenzie, w. (1830) 'Practical Treatise of the Diseases of the Eye', p. 406. London 
MANN, w. A., and Markson, D. E. (1950) Amer. F. Ophthal., 33, 459

ROGNETTA, A. (I 844) 'Traité philosophique et clinique d'ophtalmologie', p. 275. Paris

SEvEL, D. (1967) Amer. F. Ophthal., 64, I125 , and ABRAMSON, A. (1972) Brit. F. Ophthal., 56, 791

SLADE, J. (1838) 'Ophthalmia', p. 23. London

TORCHIA, K. T., DUNN, R. E., and PEASE, P. J. (1968) Amer. F. Ophthal., 66, 705

vancea, P., vancea, P.-P., JalobceastiI, L., Colev, G., and Calin, A. (I97I) Arch. Ophtal. (Paris), 31, 687

VAN DER HOEVE, J. (1934) Arch. Ophthal. (Chicago), II, I I I

verhoefF, F. H., and KING, R. J. (1938) Arch. Ophthal., 20, 1013

viswalingham, A. (1936) Brit. F. Ophthal., 20, 449

watson, P. G. (1974) Trans. ophthal. Soc. UK, 94, 773

, LOBASCHER, D. J., SABISTON, D. W., LEWIS-FANING, E., FOWLER, P. D., and JONES, B. R. (1966) Brit. $\mathcal{F}$.

Ophthal., 50, 463

, MCKAY, D. A. R., CLEMETT, R. S., and WILKINSON, P. (1973) Ibid., 57, 866

Williamson, J. (1974) Trans. ophthal. Soc. UK, 94, 742

wooD, D. J. (1936) Brit. F. Ophthal., 20, 510 